IZA DP No. 6891

Shadow Economies in Highly Developed OECD Countries: What Are the Driving Forces?

Friedrich Schneider Andreas Buehn

October 2012 


\title{
Shadow Economies in Highly Developed OECD Countries: What Are the Driving Forces?
}

\author{
Friedrich Schneider \\ Johannes Kepler University of Linz \\ and IZA
}

Andreas Buehn

USE, Utrecht University

\section{Discussion Paper No. 6891 October 2012}

\author{
IZA \\ P.O. Box 7240 \\ 53072 Bonn \\ Germany \\ Phone: +49-228-3894-0 \\ Fax: +49-228-3894-180 \\ E-mail: iza@iza.org
}

\begin{abstract}
Any opinions expressed here are those of the author(s) and not those of IZA. Research published in this series may include views on policy, but the institute itself takes no institutional policy positions. The IZA research network is committed to the IZA Guiding Principles of Research Integrity.

The Institute for the Study of Labor (IZA) in Bonn is a local and virtual international research center and a place of communication between science, politics and business. IZA is an independent nonprofit organization supported by Deutsche Post Foundation. The center is associated with the University of Bonn and offers a stimulating research environment through its international network, workshops and conferences, data service, project support, research visits and doctoral program. IZA engages in (i) original and internationally competitive research in all fields of labor economics, (ii) development of policy concepts, and (iii) dissemination of research results and concepts to the interested public.
\end{abstract}

IZA Discussion Papers often represent preliminary work and are circulated to encourage discussion. Citation of such a paper should account for its provisional character. A revised version may be available directly from the author. 


\section{ABSTRACT}

\section{Shadow Economies in Highly Developed OECD Countries: What Are the Driving Forces?}

In this paper the main focus lies on "driving forces" of the development and size of the shadow economy in highly developed 39 OECD countries. The influential factors on the shadow economy are tax policies and state regulation, which, if they rise, increase the shadow economy, but also other factors like economic ones (unemployment) are considered, too. Specifically it is shown that the main driving forces are unemployment, self-employment and the tax burden, which have different weights in these 39 countries. Between 1999 and 2010 indirect taxes have by far the largest relative impact $(29.4 \%)$, followed by selfemployment (22.2\%), unemployment (16.9\%), personal income taxes (13.1\%) and tax morale (9.5\%).

JEL Classification: K42, H26, D78

Keywords: $\quad$ shadow economy, tax morale, tax pressure, state regulation, undeclared work

Corresponding author:

Friedrich Schneider

Department of Economics

Johannes Kepler University of Linz

Altenbergerstr. 69

4040 Linz

Austria

E-mail: friedrich.schneider@jku.at 


\section{INTRODUCTION}

Fighting the shadow economy or tax evasion have been important policy goals in OECD countries for decades. Doing so requires profound knowledge about the size and development of the shadow economy, the individuals who engage in those activities, and the incentives that motivate them. That information would enable governments to better formulate policy measures that either deter shadow economic activities or incentivize their transformation into official ones. Of course, these are obvious goals of economic policy. However, in the light of the recent financial and world-wide economic crisis governments across Europe are even more interested doing so as they urgently need to reduce their "mountains" of debt built up by bailing out banks, other financial intermediaries and even entire southern European countries. In this paper we will provide a new analysis to what extent a particular determinant contributes to the size and development of the shadow economy and how that relative impact differs across different countries. We will answer questions such as whether the direct or indirect tax burden is relatively more important and how much an improving labor market may contribute. ${ }^{1}$ Governments thus have a toolbox at hand to reduce shadow economic activities most efficiently.

The reminder of the paper is organized as follows: Section 2 presents some theoretical considerations about the shadow economy. In section 3, the most important section, we first present a MIMIC model estimation of causal variables influencing indicator variables of 39 OECD-countries and then estimates of the shadow economies' size in those countries over the period 1999-2010. In a second step we analyze the relative impact of the causal variables on the size and development of the shadow economy, paying particular attention to Austria, France, Germany, Italy and Spain. Finally, section 4 provides a summary and some policy conclusions.

\section{THEORETIZING ABOUT THE SHADOW ECONOMY}

A useful starting point for a theoretical discussion of the shadow economy is the paper by Allingham and Sandmo (1972) on income tax evasion. While the shadow economy and tax evasion are not congruent, activities in the shadow economy in most cases imply the evasion

1. Our paper focuses on the size and development of the shadow economy for "uniform" countries and not for specific regions. Recently, first studies have been published aiming to measure the size of the shadow economy as well as the "grey" or "shadow" labor force for urban regions or states. See e.g. Williams and Windebank (2001), Marcelli (2004), Tafenau, Herwartz and Schneider (2010), and Buehn (2012). 
of direct or indirect taxes, such that the factors affecting tax evasion will most certainly also affect the shadow economy. According to Allingham and Sandmo tax compliance depends on its expected costs and benefits. The benefits of tax non-compliance result from the individual marginal tax rate and the true individual income. In the case of the shadow economy the individual marginal tax rate is often roughly calculated using the overall tax burden from indirect and direct taxes including social security contributions. The expected costs of non-compliance derive from deterrence enacted by the state, i.e., the state's auditing activities raising the probability of detection and the fines individuals face when they are caught. Individual morality also plays a role for compliance and additional costs could pertain beyond the tax administration's pure punishment in the form of psychic costs like shame or regret, but also additional pecuniary costs if, for example, a reputation loss results.

In summary, individuals are rational calculators who weight the costs and benefits a legal status entails. Their decision to partially or completely participate in the shadow economy is a choice under uncertainty facing a trade-off between the gains if their activities are not discovered and a loss if discovered and penalized. Shadow economic activities $S E$ thus negatively depend on the probability of detection $p$ and potential fines $f$, and positively on the opportunity costs of remaining formal denoted as $B$. The opportunity costs are positively determined by the burden of taxation $T$ and high labour costs $W$ - the individual income generated in the shadow economy is usually categorized as labor income rather than capital income - due to labour market regulations. Hence, the higher the tax burden and labor costs, the more incentives individuals have to avoid those costs by working in the shadow economy. The probability of detection $p$ itself depends on enforcement actions $A$ taken by the tax authority and on facilitating activities $F$ accomplished by individuals to reduce detection of shadow economic activities. This discussion suggests the following structural equation ${ }^{(1)}$

$$
\mathscr{S E}=\mathscr{S E} p(\stackrel{+}{A} \bar{F}) ; \bar{f} ; \stackrel{+}{B}(\stackrel{+}{T}, \stackrel{+}{W})],
$$

and definition of the shadow economy: The shadow economy comprises all economic activities and income earned that circumvent government regulation, taxation or observation. More narrowly, the shadow economy includes monetary and non-monetary transaction of legal nature, hence all productive economic activities that would generally be taxable were they reported to the state (tax) authorities. Those activities are deliberately concealed from public authorities to avoid payment of income, value added or other taxes and social security contributions, to avoid compliance with certain legal labor market standards, such as minimum 
wages, maximum working hours, or safety standards and administrative procedures. The shadow economy thus focuses on productive economic activities that would normally be included in the national accounts but which remain underground due to tax or regulatory burdens. ${ }^{2}$ Although such legal activities would contribute to the country's value added, they are not captured in the national accounts because they are produced in illicit ways. Illegal activities that fit the characteristics of classical crimes such as the trade and barter of drugs or the smuggling of contraband and human trafficking are typically excluded in the analysis of shadow economic activities, as are informal household economic activities such as do-ityourself activities and neighborly help. ${ }^{3}$

Kanniainen, Pääkönen and Schneider (2004) incorporate many of these insights in their model of the shadow economy. They hypothesize that tax hikes unambiguously increase the shadow economy, while the availability of public goods financed by those taxes moderates participation in the shadow economy. The latter effect however depends on the ability to access those public goods. A shortcoming of this analysis is the neglected endogeneity of tax morale and good governance, which is addressed by Feld and Frey (2007) who argue that tax compliance is the result of a complicated interaction between tax morale and deterrence measures. It must be clear to taxpayers what the rules of the game are and as deterrence measures serve as signals for the tax morale a society wants to elicit (Posner, 2000), deterrence may also crowd out the intrinsic motivation to pay taxes. Tax morale does not only increase if taxpayers perceive the public goods received in exchange for their tax payments. It may also decrease if individuals perceive political decisions for public activities or the treatment of taxpayers by the tax authorities to be unfair. Tax morale is thus not exogenously given but is influenced by deterrence and the quality of state institutions. Following the definition and equation (1), Table 1 presents an overview the most important determinants influencing the shadow economy, which will be used in our empirical analysis.

\footnotetext{
2. This definition avoids the problem of including classical crime activities, which the MIMIC procedure and the currency demand approach captures do not capture. For instance, drug dealing is independent of increasing taxes and the causal variables included in the empirical models are not linked (or causal) to classical crime activities. 3. From a social perspective, may even from an economic one, soft forms of illicit employment, such as moonlighting (e.g. construction work in private homes) and its contribution to aggregate value added may be assessed positively. For a discussion of these issues see Thomas (1992) and Buehn, Karmann and Schneider (2009). Buehn and Eichler (2009) present a MIMIC model application to smuggling and human trafficking across the U.S.-Mexico border.
} 


\begin{tabular}{|c|c|c|}
\hline Causal variable & Theoretical reasoning & References \\
\hline $\begin{array}{l}\text { Tax and Social Securi- } \\
\text { ty Contribution Bur- } \\
\text { dens }\end{array}$ & $\begin{array}{l}\text { The distortion of the overall tax burden affects labor-leisure choices and may stimu- } \\
\text { late labor supply in the shadow economy. The bigger the difference between the total } \\
\text { labor cost in the official economy and after-tax earnings (from work), the greater is } \\
\text { the incentive to reduce the tax wedge and work in the shadow economy. This tax } \\
\text { wedge depends on social security burden/payments and the overall tax burden, mak- } \\
\text { ing them to key features for the existence of the shadow economy. }\end{array}$ & $\begin{array}{l}\text { E.g. Thomas (1992), Johnson, } \\
\text { Kaufmann, and Zoido-Lobatón } \\
\text { (1998a,b), Giles (1999), Tanzi } \\
\text { (1999), (2003, 2005), Dell’Anno } \\
\text { (2007), Dell'Anno, Gomez- } \\
\text { Antonio and Alanon Pardo (2007), } \\
\text { Buehn and Schneider (2012) }\end{array}$ \\
\hline Quality of Institutions & $\begin{array}{l}\text { The quality of public institutions is another key factor of the development of the in- } \\
\text { formal sector. Especially the efficient and discretionary application of the tax code } \\
\text { and regulations by the government plays a crucial role in the decision of conducting } \\
\text { undeclared work, even more important than the actual burden of taxes and regula- } \\
\text { tions. In particular, a bureaucracy with highly corrupt government officials seems to } \\
\text { be associated with larger unofficial activity, while a good rule of law by securing } \\
\text { property rights and contract enforceability, increases the benefits of being formal. A } \\
\text { certain level of taxation, mostly spent in productive public services, characterizes } \\
\text { efficient policies. In fact, the production in the formal sector benefits from a higher } \\
\text { provision of the productive public services and is negatively affected by taxation, } \\
\text { while the shadow economy reacts in the opposite way. An informal sector developing } \\
\text { as a consequence of the failure of political institutions in promoting an efficient mar- } \\
\text { ket economy, and entrepreneurs going underground, as there is an inefficient public } \\
\text { goods provision, may reduce if institutions can be strengthened and fiscal policy gets } \\
\text { closer to the median voter's preferences. }\end{array}$ & $\begin{array}{l}\text { E.g. Johnson et al. (1998a,b), } \\
\text { Friedman, Johnson, Kaufmann, } \\
\text { and Zoido-Lobaton (2000), Dreher } \\
\text { and Schneider (2009), Dreher, } \\
\text { Kotsogiannis and Macorriston } \\
\text { (2009), Schneider (2010), Buehn } \\
\text { and Schneider (2012), Teobaldelli } \\
\text { (2011), Teobaldelli and Schneider } \\
\text { (2012) }\end{array}$ \\
\hline Regulations & $\begin{array}{l}\text { Regulations, for example labor market regulations or trade barriers, are another im- } \\
\text { portant factor that reduces the freedom (of choice) for individuals in the official } \\
\text { economy. They lead to a substantial increase in labor costs in the official economy } \\
\text { and thus provides another incentive to work in the shadow economy: countries that } \\
\text { are more heavily regulated tend to have a higher share of the unofficial economy in } \\
\text { total GDP. Especially the enforcement and not of regulation the overall extent of } \\
\text { regulation - mostly not enforced - is the key factor for the burden levied on firms and } \\
\text { individuals, making them operate in the shadow economy. }\end{array}$ & $\begin{array}{l}\text { E.g. Johnson, Kaufmann, and } \\
\text { Shleifer (1997), Johnson, Kauf- } \\
\text { mann, and Zoido-Lobatón } \\
\text { (1998b), Friedman, Johnson, } \\
\text { Kaufmann, and Zoido-Lobaton } \\
\text { (2000), Kucera and Roncolato } \\
\text { (2008) }\end{array}$ \\
\hline
\end{tabular}


Table 1: The main causes determining the shadow economy (cont.)

\begin{tabular}{|c|c|c|}
\hline Causal variable & Theoretical reasoning & References \\
\hline Public Sector Services & $\begin{array}{l}\text { An increase of the shadow economy may lead to fewer state revenues, which in turn } \\
\text { reduce the quality and quantity of publicly provided goods and services. Ultimately, } \\
\text { this may lead to increasing tax rates for firms and individuals, although the deteriora- } \\
\text { tion in the quality of the public goods (such as the public infrastructure) and of the } \\
\text { administration continues. The consequence is an even stronger incentive to partici- } \\
\text { pate in the shadow economy. Countries with higher tax revenues achieved by lower } \\
\text { tax rates, fewer laws and regulations, a better rule of law and lower corruption levels, } \\
\text { should thus have smaller shadow economies. }\end{array}$ & $\begin{array}{l}\text { E.g. Johnson, Kaufmann, and } \\
\text { Zoido-Lobatón }(1998 a, b)\end{array}$ \\
\hline Tax Morale & $\begin{array}{l}\text { The efficiency of the public sector also has an indirect effect on the size of the shad- } \\
\text { ow economy because it affects tax morale. Tax compliance is driven by a psychologi- } \\
\text { cal tax contract that entails rights and obligations from taxpayers and citizens on the } \\
\text { one hand, but also from the state and its tax authorities on the other hand. Taxpayers } \\
\text { are more heavily inclined to pay their taxes honestly if they get valuable public ser- } \\
\text { vices in exchange. However, taxpayers are honest even in cases when the benefit } \\
\text { principle of taxation does not hold, i.e. for redistributive policies, if such political } \\
\text { decisions follow fair procedures. The treatment of taxpayers by the tax authority also } \\
\text { plays a role. If taxpayers are treated like partners in a (tax) contract instead of subor- } \\
\text { dinates in a hierarchical relationship, taxpayers will stick to their obligations of the } \\
\text { psychological tax contract more easily. Hence, (better) tax morale and (stronger) so- } \\
\text { cial norms may reduce the probability of individuals to conduct undeclared work. }\end{array}$ & $\begin{array}{l}\text { E.g. Feld and Frey (2007), Kirch- } \\
\text { ler (2007), Torgler and Schneider } \\
\text { (2009), Feld and Larsen (2005, } \\
\text { 2009) }\end{array}$ \\
\hline Deterrence & $\begin{array}{l}\text { Despite the strong focus on deterrence in policies fighting the shadow economy and } \\
\text { the unambiguous insights of the traditional economic theory of tax non-compliance, } \\
\text { surprisingly little is known about the effects of deterrence from empirical studies. } \\
\text { This is due to the fact that data on the legal background and the frequency of audits } \\
\text { are not available on an international basis; even for OECD countries such data is dif- } \\
\text { ficult to collect. Either is the legal background quite complicated differentiating fines } \\
\text { and punishment according to the severity of the offense and the true income of the } \\
\text { non-complier, or tax authorities do not reveal how intensively auditing is taking } \\
\text { place. The little empirical survey evidence available demonstrates that fines and pun- } \\
\text { ishment do not exert a negative influence on the shadow economy, while the subjec- }\end{array}$ & $\begin{array}{l}\text { E.g. Andreoni, Erard and Feinstein } \\
\text { (1998), Pedersen (2003), Feld and } \\
\text { Larsen (2005, 2009) }\end{array}$ \\
\hline
\end{tabular}


tively perceived risk of detection does. However, the results are often weak and

Granger causality tests show that the size of the shadow economy can impact deter-

rence instead of deterrence reducing the shadow economy. 
From Table 1 we derive the following six hypotheses:

1. The higher the tax burden, measured by the personal income tax, payroll taxes, and/or indirect taxes, the bigger the shadow economy, ceteris paribus.

2. The lower the tax morale is, the bigger higher the shadow economy, ceteris paribus.

3. The higher unemployment is, the bigger the shadow economy, ceteris paribus.

4. The more regulated official business activities are, the bigger the shadow economy, ceteris paribus.

5. The higher the self-employment quota is, the bigger the shadow economy, ceteris paribus.

6. The lower the quality of institutions measured by the rule of law is (or lower levels of corruption), the bigger the shadow economy, ceteris paribus.

\section{ANALYZING THE SHADOW ECONOMY}

\subsection{Measurement}

Although shadow economic activities have been studied for a long time, the discussion regarding the "appropriate” methodology to assess them has not come to an end yet. ${ }^{4}$ Generally, the size of the shadow economy can be measured in two ways: at the micro level using surveys or questionnaires or alternatively indirect methods such as the currency demand or latent variable approaches making use of macroeconomic indicators. The virtue of the latter approaches - especially of the latent Multiple Indicators Multiple Causes (MIMIC) approach is that the shadow economy is formalized as the outcome of a multitude of causes like tax rates, the degree of regulation, or the level of unemployment. While those methods allow approximating the development of the shadow economy over time, direct approaches better reveal the motivation of individuals to escape into the shadow economy.

Today indirect estimation of the shadow economy is mostly based on a combination of the MIMIC procedure and the currency demand method; or the sole use of the currency demand method. The MIMIC procedure assumes that the shadow economy remains an unobservable phenomenon (latent variable) that can be estimated using measurable causes of illicit employment, e.g. the tax burden and regulation intensity, and indicators reflecting illicit activities, e.g. the currency demand or official working time. A disadvantage of the MIMIC proce-

4. For the strengths and weaknesses of the various methods see e.g. Bhattacharyya (1999), Breusch (2005), Feige (1989), Feld and Schneider (2010), Giles (1999), Schneider (2003, 2005, 2011), Schneider and Enste (2000), Tanzi (1999), Thomas (1999). 
dure is however, that it produces only relative estimates of the size and the development of the shadow economy. Thus, exogenous absolute estimates (e.g. in percent of GDP) of the shadow economy - typically taken from the currency demand method ${ }^{5}$ - are necessary to calibrate the relative MIMIC estimates into absolute shadow economy figures.

Alternatively, the size of the shadow economy is estimated by using survey methods (e.g. Isachsen and Strøm (1985), Pedersen (2003), Feld and Larsen (2005, 2009), Enste and Schneider (2006)). In order to minimize the number of respondents dishonestly replying or totally declining answers to the sensitive questions, structured interviews are undertaken (usually face-to-face) in which the respondents are slowly getting accustomed to the main purpose of the survey: The first part of the questionnaire shapes the respondents' perception to the issue at hand, the second part asks questions about the respondents' activities in the shadow economy, and the third part finally contains the usual socio-demographic questions. While the questionnaires underlying these studies are broadly comparable in design, recent attempts by the European Union to provide survey results for all EU member states run into difficulties regarding comparability (Renooy et al. 2004): the wording of the questionnaires becomes more and more cumbersome depending on the culture of different countries with respect to the underground economy. In tax compliance research, the most interesting data stem from tax audits by the US Internal Revenue Service (IRS). The Taxpayer Compliance Measurement Program (TCMP) studies actual compliance behavior of taxpayers and may be analyzed empirically (Andreoni, Erard and Feinstein, 1998). The approach of the IRS and is broader in a certain sense as tax evasion from all sources of income is considered, while the two methods discussed before aim at capturing the shadow economy or undeclared work. However, even the data obtained from the TCMP is biased because the actually detected tax non-compliance could only be the tip of the iceberg. Although the perfect data on tax non-compliance does therefore not exist, the imperfect data in this area can still provide interesting insights also regarding the size, the development and the determinants of the shadow economy and of the shadow economy labor force.

Although each method has its has its strength and weaknesses, and biases in the estimates of the shadow economy almost certainly prevail, no better data are currently available. Clearly, there can be no exact measure of the size of the shadow economy and estimates differ

5. This indirect approach assumes that cash is used for transactions in the shadow economy. It estimates a currency demand function including independent variables like the tax burden, regulation, and so forth that drive the shadow economy. The estimated equation is used to simulate that money demand necessary to generate the official GDP and compares it to actual money demand. The difference - multiplied by the velocity of money in the official economy - allows calculation of a value added figure for the shadow economy. 
widely with an error margin of +/- 15.00 percent. These days, macro estimates derived from the MIMIC model, the currency demand method, or the electricity approach are seen as upper bound estimates, while micro (survey) estimates are seen as lower bound estimates.

\subsection{Econometric results}

We analyse the shadow economies of 39 developed OECD countries over the period 1999 to 2010 using a MIMIC approach, which allows us to employ a number of potential measures of shadow economic activities, i.e., its indicators, simultaneously. Suitable indicators of shadow economic activities are currency demand, official working time or labour force participation, and official GDP. The effect of a larger shadow economy on official GDP figures can be expected to be negative, all other things being equal. The larger the shadow economy, the lower the government's tax revenues and thus the ability to provide public goods and services, i.e. public demand, that significantly contributes to official GDP. In addition, the more individuals participate in shadow economic activities, the less work officially. Hence, the expected correlation between the shadow economy and official labour market indicators can also be expected to be negative, all other things being equal. Using currency in circulation as an indicator of shadow economic activities seems most reasonable, as cash is mostly used as means of payment in the shadow economy protecting principal and agent best. The expected correlation is positive. Table 1 has already presented the most important determinants (causes) incentivizing economic agents to operate in the shadow economy. Their empirical implementation in the form of causal variables and the indicators of the MIMIC model as well as the predicted signs are given in table A.1 in the Appendix, while table 2 in the main body of the paper shows the countries included in the sample.

\section{[Insert table 2 here]}

Table 3 presents the results of five different MIMIC model specifications. The reason is that some of the causal variables which are highly correlated with each other. Turning first to the direct and indirect tax burden, we find that both causal variables are highly statistically significant and have the expected positive sign in all equations. This is not the case for the payroll taxes. Also the "soft" factor tax morale is highly statistically significant and has the predicted negative sign in all equations, i.e., a lower level of tax morale is correlated with larger shadow economies. Looking at the more economic causal variables, unemployment, business freedom, and self-employment, we also find that all three causal variables have a highly statistically significant influence and the expected signs. This holds also for GDP 
growth, which has a positive and again highly statistically significant influence. The Rule of Law is only statistically significant in specification 1 and 2, while the alternative measure of institutions, i.e., the variable corruption, is not statistically significant at all. The causal variable education is also highly statistically significant and has the expected sign indicating that the more or better people are educated on average, the less they operate in the shadow economy, all other things being equal. Concerning the indicators, the labor force participation is highly statistically significant and has the predicted negative influence, while the measure of currency in circulation is only statistically significant in specification 3 and 4 . In general the estimation results are quite satisfactory, especially as a most causal variables have the predicted sign and are highly statistically significant.

The standard coefficients presented allow to directly comparing the relative influence of the different causal variables. Table 3 clearly shows that the coefficient of the unemployment rate variable has the biggest influence on the shadow economy with a standardized coefficient between 0.53 and 0.65 ; followed by the personal income tax with a standardized coefficient between 0.27 and 0.40 ; followed by business freedom with a standardized coefficient between 0.29 and 0.35 . GDP growth and education show very similar standardized coefficients with value of 0.29 and 0.30 and between 0.27 and 0.31 , respectively. Concerning the tax burden measures, indirect and direct taxes have standardized coefficients between 0.27 and 0.40 and the tax morale variable between 0.21 and 0.3 . The dominating influence of the unemployment rate is not amazing as being unemployed quite often means a severe income loss in the official one; hence unemployed people try to compensate this income or utility loss by expanding their activities in the shadow economy.

[Insert table 3 here]

\subsection{Size and Development of the Shadow Economy of 39 OECD Countries}

In table 4 the size and development of the shadow economy of 39 countries over the period 1999 to 2010 is shown. No detailed interpretation is given here but some general trends are discussed. In most countries, the shadow economy increases in the year 2009, which is due to the world financial and economic crisis. For example in Canada the shadow economy was 14.9\% of official GDP in the year 2008 and increased to $15.5 \%$. In Chile, the shadow economy was 19.1\% of official GDP in 2008 and increased to 20.5 \% in 2009; or in Norway, the shadow economy had a size of $17.7 \%$ of official GDP in 2008 and increased to $18.6 \%$ in 
2009. The countries with the largest shadow economies are Bulgaria, Romania and Turkey with 34.6\%, 32.2\%, and 30.6\%, respectively; Luxemburg, Switzerland and the United States are the countries with the smallest shadow economies, with sizes of $9.2 \%, 8.6 \%$ and $9.0 \%$ of official GDP, respectively. The un-weighted average size of the shadow economy across the 39 OECD countries was 20.3\% of official GDP in 1999 and decreased to $18.3 \%$ in 2010.

The highlighted rows in table 4 present the size and development of the shadow economies for selected countries, i.e., for Austria, France, Germany, Italy and Spain, for which we will discuss the relative impact of the different causal variable in more detail in the next section $^{6}$. Concerning first the size of their shadow economies, table 4 shows that Austria has the lowest shadow economy with an average value of $9.8 \%$ of official GDP, while Italy has the largest with an average value of $26.9 \%$, followed by Spain with 22.8\%, Germany (15.7\%) and France (14.8\%). All five countries experienced increasing shadow economies between 1999 and 2004/05; since 2006 the shadow economy in these countries, except for Spain, decreased.

[Insert table 4 here]

\subsection{The Relative Impact of the Causal Variables on the Shadow Economy}

Tables 5 to 9 present the relative impact of the causal variables on the size of the shadow economy for the five selected countries of Austria, France, Germany, Italy and Spain over the period 1998 to 2010. Starting with the relative impact of the causal variables on the shadow economy in Austria (table 5 and figure 1) we clearly see that indirect taxes contribute most, i.e. $27.2 \%$, to the Austrian shadow economy. The second most influential causal variable is self-employment with an average relative impact of $20.5 \%$, followed by the personal income tax, which average relative impact is $18.4 \%$. The unemployment rate explains on average $12.1 \%$ of the shadow economy's variation, the variable tax morale $11.8 \%$, and the business freedom variable - measuring the impact of regulations on the ability and flexibility to run a business. Of less importance is the GDP growth rate, where the relative impact is only $1.1 \%$ on average. One reason for the low explanatory power of the GDP growth rate may be that the unemployment rate already captures a great deal of the shadow economy's variation induced by the macroeconomic environment and the business cycle. Concerning the evolution of the causal variables during the observation period we observe a decreasing relative impact of the income tax from 19.2\% (1998) to 17.8\% (2010). The contribution of indirect taxes reduced

\footnotetext{
${ }^{6}$ This selection was done under the aspect that we know these countries and that they have quite different sizes of the shadow economy.
} 
from $28.1 \%$ in 1998 to $25.6 \%$ in 2010 , while the relative impact of the variable tax morale increases from 8.4\% (1998) to 14.5\% (2010).

Looking at France - the results are shown in table 6 and figure 2 - we find that the causal variables indirect taxes and unemployment on the shadow economy are almost equally important. Their relative contribution to the shadow economy is on average $24.3 \%$ and $23.1 \%$, respectively. The relative influence of indirect taxation increases from 22.2\% in 1998 to $25.1 \%$ in 2010 . The impact of the unemployment rate decreases from $26.4 \%$ in 1998 to $22.2 \%$ in 2010. The causal variables tax morale and self-employment are also equally important having an average relative impact of $15.4 \%$ and $15.1 \%$, respectively. While the influence of the tax morale variable shrinks from 16.6\% in 1998 to 13.2\% in 2010, self-employment becomes slightly more important: its impact increases from $14.6 \%$ in 1998 and to $15.6 \%$ in 2010 . The relative influence of the personal income tax was $11 \%$ in 1998 and increased to $13.4 \%$ in 2010. The same holds for the business freedom index, which contributed 8\% in 1998 and $10.2 \%$ in 2010.

Table 7 and figure 3 present the results for Germany. Like in France, the predominant causal variables of the shadow economy are indirect taxes and the unemployment rate with average relative impacts of $24.1 \%$ and $24.7 \%$, respectively. While the influence of the indirect tax burden increased from $21.4 \%$ in 1998 to $26 \%$ in 2010, the impact of the causal variable unemployment shows the opposite movement: It decreased from $25.8 \%$ in 1998 to $21.8 \%$ in 2010. For Germany we also observe a strong decrease of the relative impact of the causal variable tax morale. It was $11.8 \%$ in 1998 and decreased to $5.6 \%$ in 2010; this is a reduction of more than 50\%!! The causal variable personal income taxation has no clear trend. The average relative contribution to estimates of the German shadow economy is $16.5 \%$. Selfemployment on the other hand shows a slightly increasing trend from $16.4 \%$ in 1998 to $17.1 \%$ in 2010. While GDP growth is not important at all with respect to the impact on the shadow economy, the relative influence of the business freedom index rose from $6.7 \%$ in 1998 to $10.7 \%$ in 2010.

The simulation results concerning the relative impact of the causal variables on the Italian shadow economy are shown in table 8 (figure 4), clearly demonstrating that the causal variable self-employment has a predominant influence, which was 29.9\% in 1998 and increased even further to 31\% in 2010. The second most important variable is unemployment with an relative impact of $23.6 \%$ in 1998 , which however decreased to $15.6 \%$ in 2010 . While the indirect tax variable shows no clear trend, its average relative impact is $18 \%$, the causal variable personal income contributed $13.6 \%$ to shadow economy estimate in 1998 and $17.4 \%$ in 2010 . 
The relative impact of the variables tax morale and business freedom shows a similar pattern, both slightly increased between 1998 and 2010. The increase of the tax morale variable was $0.8 \%$ from $8.5 \%$ (1998) to $9.3 \%$ (2010) and that of the business freedom index $1.8 \%$ from $5.9 \%$ in 1998 to $7.7 \%$ in 2010.

Finally table 9 and figure 5 present the relative impact of the causal variables on the Spanish shadow economy during 1998 and 2010. We find a predominant relative impact of the causal variable unemployment; its average contribution to the development of the Spanish shadow economy is $27.8 \%$; however the influence decreased from $35.2 \%$ in 1998 to $31 \%$ in 2010. The second most-important determinant is self-employment with an average relative impact of 23.8\% that was almost stable between 1998 and 2010. Changes of the indirect tax burden contribute $17.8 \%$ to the shadow economy; this variable's impact however decreased between 1998 and 2010. The average impact of causal variables indirect taxes and tax morale is similarly important regarding their impact on the size and development of the shadow economy. The personal income tax contributed 8.7\% in 1998 and the relative impact of tax morale was $8 \%$ in that year. For both variables the influence increased to $11.7 \%$ in 2010 . Finally, the business freedom index gained importance between 1998 and 2010: Its relative impact increased from 5.7\% in 1998 to $8.9 \%$ in 2010.

In general the simulation results for the selected 5 OECD-countries clearly demonstrate that the determinants of the shadow economy are not equally important across countries. For that reason, table 10 presents the average relative influence (in \%) of the causal variables to the size and development of the shadow economies in all 39 OECD countries between 1999 and 2010. We see that indirect taxation, unemployment, and self-employment are the most influential determinants of the shadow economy for the majority of countries. Looking at the average values in the last row of table 10 first, we observe clearly that indirect taxes have by far the predominant influence (29.4\%) across countries. It is followed by self-employment with an average relative impact of $22.2 \%$, then by the unemployment rate (16.9\%), the personal income tax (13.1\%), tax morale (9.5\%), the business freedom index (8.1\%), and finally GDP growth with an average relative impact of only $0.9 \%$. Considering single variables, the personal income tax shows a large variance with respect to the relative impact on the shadow economy. It has a very large relative impact in Denmark (34.6\%) and the United States (27.5\%), while the impact in Chile (1.8\%) and Mexico (2.3\%) is almost negligible. The relative impact of indirect taxes concerning the shadow economy's evolution is largest in Mexico (42.1\%), followed by Malta and Iceland (39.7\%); the relative impact of indirect taxes is smallest in the United States (5.1\%) and Canada (17.5\%). The tax morale variable has the 
highest relative impact on the shadow economy in Luxembourg with an average value of 20\% between 1999 and 2010, and the lowest in Turkey (0.7\%). The unemployment variable has the largest impact in Spain (29.2\%), followed by Poland (26.1\%). The relative impact of the unemployment rate is smallest in Iceland (7.1\%), Denmark (9.5\%) and Switzerland (9.6\%). Self-employment is on average most important in Korea (44.3\%), Turkey (41.4\%), Romania (37.7\%) and Greece (37.6\%). Again, table 10 demonstrates that - as one would expect - the 39 OECD countries are very different regarding the influence of the causal variables on the size and development of the shadow economy.

\section{SUMMARY AND CONCLUSIONS}

Our paper has first theoretically discussed the importance of the determinants of shadow economic activities, like the direct and indirect tax burden, tax morale, unemployment, selfemployment and other factors. We have then presented estimates of the size and development of the shadow economy for 39 countries using a MIMIC approach. The estimation results show that the causal variables personal income tax, indirect taxes, tax morale, unemployment, self-employment, GDP growth and business freedom have the theoretically expected signs and are highly statistically significant. Considering the MIMIC model’s standardized coefficients, we find that unemployment has by far the largest influence, followed by the personal income tax and GDP growth. Calculating the size and development of the shadow economy for these 39 countries, Bulgaria, Romania and Turkey have the largest shadow economies between 1999 and 2010 with average sizes of 34.6\%, 32.2\% and 30.6\% of official GDP, respectively. The shadow economies in Switzerland, the United States, and Luxembourg are the smallest, with average sizes of $8.3 \%, 8.7 \%$ and $9.6 \%$ of official GDP, respectively. Looking at the average relative impact of the causal variables on the shadow economy across the 39 OECD-countries between 1999 and 2010 it turns out that indirect taxes have by far the largest relative impact (29.4\%), followed by self-employment (22.2\%), unemployment (16.9\%), personal income taxes (13.1\%) and finally tax morale (9.5\%).

The final question remaining is what type of policy conclusions we can draw? One conclusion may be that - besides the indirect tax and personal income tax burden, which the government can directly influence by policy actions - self-employment and unemployment are two very important driving forces of the shadow economy. Unemployment may be controllable by the government through economic policy in a traditional Keynesian sense; alternatively, the government can try to improve the country's competitiveness to increase foreign de- 
mand. The impact of self-employment on the shadow economy is less or only partly controllable by the government and may be ambiguous from a welfare perspective. A government can deregulate the economy or incentivize "to be your own entrepreneur", which would make self-employment easier, potentially reduce unemployment positively contributing to efforts in controlling the size of the shadow economy. Such actions however need to be accompanied with a strengthening of institutions and tax morale to reduce the probability that selfemployed shift reasonable proportions of their economic activities into the shadow economy, which, if it happened, made government policies supporting self-employment less effective.

Our paper clearly shows that a reduction of the shadow economy can be achieved using various channels the government can influence. The main challenge still is to bring shadow economy activities into the official economy, so that goods and services are still produced and provided, while the government gets additional taxes and social security contributions.

\section{TABLES}

Table 2: OECD countries included in the sample; estimation period: 1998/99-2010 Australia, Austria, Belgium, Bulgaria, Canada, Chile, Cyprus, Czech Republic, Denmark, Estonia, Finland, France, Germany, Greece, Hungary, Iceland, Ireland, Italy, Japan, Korea, Latvia, Lithuania, Luxembourg, Malta, Mexico, Netherlands. New Zealand, Norway, Poland, Portugal, Romania, Slovak Republic, Slovenia, Spain, Sweden, Switzerland, Turkey, United Kingdom, United States 
Table 3: MIMIC model estimations (standardized coefficients)

\begin{tabular}{|c|c|c|c|c|c|}
\hline Specification & 1 & 2 & 3 & 4 & 5 \\
\hline \multicolumn{6}{|l|}{ Causes } \\
\hline Personal income tax & $\begin{array}{c}0.27 * * * \\
(3.27)\end{array}$ & $\begin{array}{c}0.33^{* * * *} \\
(3.99)\end{array}$ & $\begin{array}{c}0.37 * * * \\
(4.30)\end{array}$ & $\begin{array}{c}0.40 * * * \\
(4.80)\end{array}$ & $\begin{array}{c}0.39 * * * \\
(4.74)\end{array}$ \\
\hline Payroll taxes & $\begin{array}{l}-0.08 \\
(0.98)\end{array}$ & $\begin{array}{l}-0.11 \\
(1.35)\end{array}$ & & & \\
\hline Indirect taxes & $\begin{array}{c}0.24^{* * *} \\
(2.75)\end{array}$ & $\begin{array}{c}0.22 * * * \\
(2.66)\end{array}$ & $\begin{array}{c}0.31^{* * *} \\
(3.85)\end{array}$ & $\begin{array}{c}0.21 * * * \\
(2.67)\end{array}$ & $\begin{array}{c}0.24 * * * \\
(2.97)\end{array}$ \\
\hline Tax morale & $\begin{array}{c}-0.31 * * * \\
(3.29)\end{array}$ & $\begin{array}{c}-0.22 * * * \\
(2.40)\end{array}$ & $\begin{array}{c}-0.26 * * * \\
(2.84)\end{array}$ & $\begin{array}{c}-0.22 * * * \\
(2.51)\end{array}$ & $\begin{array}{c}-0.21 * * * \\
(2.38)\end{array}$ \\
\hline Unemployment & $\begin{array}{c}0.63^{* * *} \\
(5.92)\end{array}$ & $\begin{array}{c}0.65^{* * * *} \\
(6.30)\end{array}$ & $\begin{array}{c}0.63^{* * * *} \\
(5.96)\end{array}$ & $\begin{array}{c}0.55^{* * * *} \\
(5.56)\end{array}$ & $\begin{array}{c}0.53 * * * \\
(5.47)\end{array}$ \\
\hline Business freedom & $\begin{array}{c}-0.29 * * * \\
(3.35)\end{array}$ & $\begin{array}{c}-0.26 * * * \\
(3.11)\end{array}$ & $\begin{array}{c}-0.29 * * * \\
(3.36)\end{array}$ & $\begin{array}{c}-0.35 * * * \\
(4.06)\end{array}$ & $\begin{array}{c}-0.35^{* * *} \\
(4.20)\end{array}$ \\
\hline Self-employment & $\begin{array}{c}0.29 * * * \\
(2.68)\end{array}$ & $\begin{array}{c}0.30 * * * \\
(2.88)\end{array}$ & $\begin{array}{c}0.34 * * * \\
(3.17)\end{array}$ & $\begin{array}{c}0.33 * * * \\
(3.18)\end{array}$ & $\begin{array}{c}0.27 * * * \\
(2.57)\end{array}$ \\
\hline Rule of Law & $\begin{array}{l}-0.14^{*} \\
(1.81)\end{array}$ & $\begin{array}{l}-0.14^{*} \\
(1.83)\end{array}$ & $\begin{array}{l}-0.10 \\
(1.31)\end{array}$ & $\begin{array}{l}-0.08 \\
(1.03)\end{array}$ & \\
\hline GDP growth & & $\begin{array}{c}0.30 * * * \\
(3.62)\end{array}$ & $\begin{array}{c}0.31 * * * \\
(3.70)\end{array}$ & $\begin{array}{c}0.27 * * * \\
(3.35)\end{array}$ & $\begin{array}{c}0.29 * * * \\
(3.52)\end{array}$ \\
\hline Education & & & & $\begin{array}{c}-0.31 * * * \\
(3.51)\end{array}$ & $\begin{array}{c}-0.26 * * * \\
(2.83)\end{array}$ \\
\hline Corruption & & & & & $\begin{array}{c}0.14 \\
(1.56)\end{array}$ \\
\hline \multicolumn{6}{|l|}{ Indicators } \\
\hline GDP pc & -0.52 & -0.52 & -0.48 & -0.51 & -0.50 \\
\hline Currency in circulation & $\begin{array}{c}0.09 \\
(1.39)\end{array}$ & $\begin{array}{c}0.07 \\
(1.07)\end{array}$ & $\begin{array}{l}0.10^{*} \\
(1.75)\end{array}$ & $\begin{array}{l}0.10^{*} \\
(1.69)\end{array}$ & $\begin{array}{c}0.08 \\
(1.26)\end{array}$ \\
\hline Labour force participation & $\begin{array}{c}-0.56 * * * \\
(6.42)\end{array}$ & $\begin{array}{c}-0.55 * * * \\
(6.58)\end{array}$ & $\begin{array}{c}-0.52 * * * \\
(6.36)\end{array}$ & $\begin{array}{c}-0.50 * * * \\
(6.48)\end{array}$ & $\begin{array}{c}-0.51^{* * *} \\
(6.46)\end{array}$ \\
\hline Observations & 151 & 151 & 151 & 151 & 151 \\
\hline Degrees Freedom & 44 & 54 & 42 & 52 & 52 \\
\hline Chi-square & 88.88 & 89.68 & 24.10 & 32.51 & 34.57 \\
\hline RMSEA & 0.08 & 0.06 & 0.00 & 0.00 & 0.00 \\
\hline
\end{tabular}

Note: The sample includes 39 OECD countries and the estimation period is 1998 to 2010 . Absolute z-statistics are reported in parentheses. * , **, *** indicate significance at the $10 \%$, $5 \%$, and $1 \%$ level, respectively. 
Table 4: Size and development of the shadow economy (in \% of GDP) ${ }^{1)}$ in 39 OECD countries

\begin{tabular}{|c|c|c|c|c|c|c|c|c|c|c|c|c|c|}
\hline Country & 1999 & 2000 & 2001 & 2002 & 2003 & 2004 & 2005 & 2006 & 2007 & 2008 & 2009 & 2010 & $\begin{array}{c}\text { Aver- } \\
\text { age }\end{array}$ \\
\hline Australia & 14.4 & 14.3 & 14.3 & 14.1 & 13.9 & 13.7 & 13.7 & 13.7 & 13.7 & 13.2 & 13.5 & 13.4 & 13.8 \\
\hline Austria & 10.0 & 9.8 & 9.7 & 9.8 & 9.8 & 9.8 & 9.8 & 9.6 & 9.7 & 9.5 & 9.7 & 10.6 & 9.8 \\
\hline Belgium & 22.7 & 22.2 & 22.1 & 22.0 & 22.0 & 21.8 & 21.8 & 21.4 & 20.8 & 20.3 & 20.5 & 20.7 & 21.5 \\
\hline Bulgaria & 37.3 & 36.9 & 36.6 & 36.1 & 35.6 & 34.9 & 34.1 & 33.5 & 33.0 & 33.7 & 32.1 & 31.9 & 34.6 \\
\hline Canada & 16.3 & 16 & 15.9 & 15.8 & 15.7 & 15.6 & 15.5 & 15.3 & 15.2 & 14.9 & 15.5 & 15.4 & 15.6 \\
\hline Chile & 19.9 & 19.8 & 19.6 & 19.6 & 19.4 & 19.1 & 18.9 & 18.7 & 18.4 & 19.1 & 20.5 & 19.8 & 19.4 \\
\hline Cyprus & 29.2 & 28.7 & 28.2 & 27.8 & 28.2 & 28.1 & 27.7 & 27.3 & 27.3 & 27.7 & 26.9 & 25.4 & 27.7 \\
\hline Czech Rep. & 19.3 & 19.1 & 18.9 & 18.8 & 18.7 & 18.4 & 17.8 & 17.3 & 16.3 & 15.2 & 15.7 & 15.5 & 17.6 \\
\hline Denmark & 18.4 & 18.0 & 18.0 & 18.0 & 18.0 & 17.8 & 17.6 & 17.0 & 16.5 & 15.3 & 16.2 & 16.2 & 17.3 \\
\hline Estonia & - & 25.6 & 25.3 & 24.9 & 24.3 & 24.0 & 23.4 & 22.7 & 22.5 & 20.8 & 24.3 & 22.5 & 21.7 \\
\hline Finland & 18.4 & 18.1 & 17.9 & 17.8 & 17.7 & 17.6 & 17.4 & 17.1 & 16.6 & 16.4 & 16.7 & 16.8 & 17.4 \\
\hline France & 15.7 & 15.2 & 15.0 & 15.1 & 15.0 & 14.9 & 14.8 & 14.8 & 14.5 & 14.0 & 14.5 & 14.6 & 14.8 \\
\hline Germany & 16.4 & 16.0 & 15.9 & 16.1 & 16.3 & 16.1 & 16.0 & 15.6 & 15.3 & 14.8 & 14.6 & 15.1 & 15.7 \\
\hline Greece & 28.5 & 28.7 & 28.2 & 28.0 & 27.4 & 27.1 & 26.9 & 26.4 & 26.5 & 26.0 & 25.3 & 25.1 & 27.0 \\
\hline Hungary & 25.4 & 25.1 & 24.8 & 24.5 & 24.4 & 24.1 & 24.0 & 23.7 & 23.7 & 23.1 & 23.1 & 23.1 & 24.1 \\
\hline Iceland & 16.0 & 15.9 & 15.8 & 16.0 & 15.9 & 15.5 & 15.1 & 15.0 & 14.4 & 13.8 & 14.7 & 14.4 & 15.2 \\
\hline Ireland & 16.1 & 15.9 & 15.9 & 15.9 & 16.0 & 15.8 & 15.6 & 15.5 & 15.9 & 15.9 & 17.5 & 16.5 & 16.1 \\
\hline Italy & 27.8 & 27.1 & 26.7 & 26.8 & 27.0 & 27.0 & 27.1 & 26.9 & 26.8 & 26.7 & 26.5 & 26.7 & 26.9 \\
\hline Japan $^{2}$ & 11.4 & 11.2 & 11.2 & 11.3 & 11.2 & 10.9 & 10.7 & 10.4 & 10.3 & 11.0 & 11.0 & 11.0 & 11.0 \\
\hline Korea, Rep. & 28.3 & 27.5 & 27.3 & 26.9 & 26.8 & 26.5 & 26.3 & 25.9 & 25.8 & 25.6 & 24.5 & 24.7 & 26.3 \\
\hline Latvia & 23.9 & 23.6 & 23.2 & 22.9 & 22.5 & 22.1 & 21.5 & 20.8 & 20.8 & 22.6 & 20.0 & 21.5 & 22.1 \\
\hline Lithuania & 27.2 & 27.1 & 26.7 & 26.2 & 25.4 & 25.1 & 24.4 & 23.8 & 24.3 & 26.0 & 23.6 & 25.4 & 25.4 \\
\hline Luxembourg & 10.0 & 9.8 & 9.8 & 9.8 & 9.8 & 9.8 & 9.7 & 9.6 & 9.3 & 9.1 & 9.3 & 9.6 & 9.6 \\
\hline
\end{tabular}


Table 4: Size and development of the shadow economy (in \% of GDP) ${ }^{1)}$ in 39 OECD countries (continued)

\begin{tabular}{|c|c|c|c|c|c|c|c|c|c|c|c|c|c|}
\hline Country & 1999 & 2000 & 2001 & 2002 & 2003 & 2004 & 2005 & 2006 & 2007 & 2008 & 2009 & 2010 & $\begin{array}{c}\text { Aver- } \\
\text { age }\end{array}$ \\
\hline Malta & 27.4 & 27.1 & 27.3 & 27.3 & 27.5 & 27.6 & 27.3 & 27.0 & 26.8 & 27.0 & 26.7 & 28.1 & 27.3 \\
\hline Mexico $^{2}$ & 30.8 & 30.1 & 30.3 & 30.4 & 30.5 & 30.1 & 29.9 & 29.2 & 28.8 & 30.0 & 30.0 & 30.0 & 30.0 \\
\hline Netherlands & 13.3 & 13.1 & 13.1 & 13.2 & 13.3 & 13.2 & 13.2 & 13.2 & 13.1 & 12.7 & 12.9 & 13.6 & 13.2 \\
\hline New Zealand & 13.0 & 12.8 & 12.6 & 12.4 & 12.2 & 12.0 & 12.1 & 12.1 & 12.0 & 11.8 & 12.0 & 12.0 & 12.2 \\
\hline Norway & 19.2 & 19.1 & 19.0 & 19.0 & 19.0 & 18.5 & 18.5 & 18.2 & 18.1 & 17.7 & 18.6 & 18.2 & 18.6 \\
\hline Poland & 27.7 & 27.6 & 27.7 & 27.7 & 27.5 & 27.3 & 26.9 & 26.4 & 25.4 & 24.7 & 24.6 & 23.8 & 26.4 \\
\hline Portugal & 23.0 & 22.7 & 22.6 & 22.7 & 23.0 & 23.1 & 23.3 & 23.2 & 22.5 & 21.9 & 22.0 & 22.2 & 22.7 \\
\hline Romania & 34.3 & 34.4 & 33.7 & 33.5 & 32.8 & 32.0 & 31.7 & 30.7 & 30.8 & 31.5 & 30.0 & 30.9 & 32.2 \\
\hline Slovak Rep. & 18.9 & 18.9 & 18.8 & 18.6 & 18.3 & 18.1 & 17.6 & 17.2 & 16.6 & 16.0 & 15.8 & 15.8 & 17.5 \\
\hline Slovenia & 27.3 & 27.1 & 26.7 & 26.6 & 26.4 & 26.2 & 25.8 & 25.3 & 25.3 & 24.6 & 23.5 & 23.7 & 25.7 \\
\hline Spain & 23.0 & 22.7 & 22.4 & 22.4 & 22.4 & 22.5 & 22.4 & 22.4 & 22.3 & 22.9 & 24.5 & 23.5 & 22.8 \\
\hline Sweden & 19.6 & 19.2 & 19.1 & 19.0 & 18.7 & 18.5 & 18.6 & 18.2 & 18.0 & 17.7 & 17.9 & 18.1 & 18.6 \\
\hline Switzerland & 8.8 & 8.6 & 8.6 & 8.6 & 8.8 & 8.6 & 8.5 & 8.3 & 8.0 & 7.2 & 7.8 & 8.0 & 8.3 \\
\hline Turkey & 32.7 & 32.1 & 32.8 & 32.4 & 31.8 & 31.0 & 30.0 & 29.5 & 28.0 & 28.6 & 29.4 & 29.0 & 30.6 \\
\hline $\begin{array}{l}\text { United King- } \\
\text { dom }\end{array}$ & 12.8 & 12.7 & 12.6 & 12.6 & 12.5 & 12.4 & 12.4 & 12.3 & 12.4 & 12.1 & 12.9 & 12.0 & 12.5 \\
\hline United States & 8.8 & 8.7 & 8.8 & 8.8 & 8.7 & 8.6 & 8.5 & 8.4 & 8.6 & 8.6 & 9.3 & 9.1 & 8.7 \\
\hline Average & 20.3 & 20.7 & 20.6 & 20.5 & 20.4 & 20.1 & 19.9 & 19.6 & 19.3 & 19.2 & 18.3 & 18.3 & 20.3 \\
\hline
\end{tabular}

Source: Own calculations

1) Estimates before 2007 are taken from Buehn and Schneider (2012).

2) Data for 2009 and 2010 are not available for all causes, hence 2009 and 2010 estimates are a linear interpolation of the 2008 estimate and the country average. 
Table 5: The relative impact of the causal variables on the shadow economy of AUSTRIA over 1998 to 2010

\begin{tabular}{|c|c|c|c|c|c|c|c|}
\hline$\frac{\text { Austria }}{\text { Year }}$ & $\begin{array}{c}\text { Personal } \\
\text { Income Tax } \\
\text { (PIT) }\end{array}$ & Indirect taxes & Tax morale & Unemployment & $\begin{array}{c}\text { Self- } \\
\text { employment }\end{array}$ & GDP growth & $\begin{array}{l}\text { Business free- } \\
\text { dom }\end{array}$ \\
\hline 1998 & $19.2 \%$ & $28.1 \%$ & $8.4 \%$ & $12.3 \%$ & $21.5 \%$ & $1.7 \%$ & $8.9 \%$ \\
\hline 1999 & $19.6 \%$ & $28.7 \%$ & $8.7 \%$ & $10.9 \%$ & $21.6 \%$ & $1.5 \%$ & $9.0 \%$ \\
\hline 2000 & $19.0 \%$ & $28.8 \%$ & $9.5 \%$ & $10.4 \%$ & $21.5 \%$ & $1.8 \%$ & $9.0 \%$ \\
\hline 2001 & $20.4 \%$ & $28.1 \%$ & $10.3 \%$ & $10.7 \%$ & $21.3 \%$ & $0.1 \%$ & $9.0 \%$ \\
\hline 2002 & $19.2 \%$ & $28.5 \%$ & $10.7 \%$ & $11.5 \%$ & $20.8 \%$ & $0.5 \%$ & $8.7 \%$ \\
\hline 2003 & $19.0 \%$ & $28.7 \%$ & $11.3 \%$ & $12.3 \%$ & $19.8 \%$ & $0.2 \%$ & $8.7 \%$ \\
\hline 2004 & $18.2 \%$ & $27.8 \%$ & $11.8 \%$ & $13.7 \%$ & $19.3 \%$ & $0.9 \%$ & $8.5 \%$ \\
\hline 2005 & $17.2 \%$ & $27.1 \%$ & $12.4 \%$ & $14.4 \%$ & $19.7 \%$ & $0.8 \%$ & $8.4 \%$ \\
\hline 2006 & $17.1 \%$ & $25.9 \%$ & $13.0 \%$ & $12.9 \%$ & $19.8 \%$ & $1.4 \%$ & $9.8 \%$ \\
\hline 2007 & $17.1 \%$ & $25.4 \%$ & $13.6 \%$ & $12.0 \%$ & $20.7 \%$ & $1.6 \%$ & $9.6 \%$ \\
\hline 2008 & $18.4 \%$ & $25.5 \%$ & $14.6 \%$ & $10.6 \%$ & $20.4 \%$ & $0.8 \%$ & $9.8 \%$ \\
\hline 2009 & $17.2 \%$ & $25.1 \%$ & $14.2 \%$ & $13.0 \%$ & $19.4 \%$ & $1.9 \%$ & $9.2 \%$ \\
\hline 2010 & $17.8 \%$ & $25.6 \%$ & $14.5 \%$ & $12.0 \%$ & $20.4 \%$ & $0.8 \%$ & $8.8 \%$ \\
\hline Average & $18.4 \%$ & $27.2 \%$ & $11.8 \%$ & $12.1 \%$ & $20.5 \%$ & $1.1 \%$ & $9.0 \%$ \\
\hline
\end{tabular}


Table 6: The relative impact of the causal variables on the shadow economy of FRANCE over 1998 to 2010

\begin{tabular}{|c|c|c|c|c|c|c|c|}
\hline$\frac{\text { France }}{\text { Year }}$ & $\begin{array}{c}\text { Personal } \\
\text { Income Tax } \\
\text { (PIT) }\end{array}$ & Indirect taxes & Tax morale & Unemployment & $\begin{array}{c}\text { Self- } \\
\text { employment }\end{array}$ & GDP growth & $\begin{array}{c}\text { Business free- } \\
\text { dom }\end{array}$ \\
\hline 1998 & $11.0 \%$ & $22.2 \%$ & $16.6 \%$ & $26.4 \%$ & $14.6 \%$ & $1.1 \%$ & $8.0 \%$ \\
\hline 1999 & $11.5 \%$ & $22.1 \%$ & $16.7 \%$ & $26.3 \%$ & $14.3 \%$ & $1.1 \%$ & $8.1 \%$ \\
\hline 2000 & $12.6 \%$ & $23.3 \%$ & $17.3 \%$ & $24.1 \%$ & $14.4 \%$ & $1.2 \%$ & $7.2 \%$ \\
\hline 2001 & $13.2 \%$ & $24.3 \%$ & $17.8 \%$ & $21.8 \%$ & $14.7 \%$ & $0.5 \%$ & $7.7 \%$ \\
\hline 2002 & $12.8 \%$ & $25.2 \%$ & $17.2 \%$ & $22.3 \%$ & $14.7 \%$ & $0.1 \%$ & $7.8 \%$ \\
\hline 2003 & $12.8 \%$ & $25.4 \%$ & $16.3 \%$ & $22.0 \%$ & $15.7 \%$ & $0.1 \%$ & $7.7 \%$ \\
\hline 2004 & $12.5 \%$ & $25.0 \%$ & $15.5 \%$ & $23.4 \%$ & $15.1 \%$ & $0.8 \%$ & $7.7 \%$ \\
\hline 2005 & $13.7 \%$ & $24.8 \%$ & $15.0 \%$ & $22.9 \%$ & $15.3 \%$ & $0.5 \%$ & $7.9 \%$ \\
\hline 2006 & $13.2 \%$ & $24.3 \%$ & $14.0 \%$ & $22.6 \%$ & $15.4 \%$ & $0.8 \%$ & $9.8 \%$ \\
\hline 2007 & $13.3 \%$ & $25.0 \%$ & $13.8 \%$ & $21.5 \%$ & $15.6 \%$ & $0.7 \%$ & $10.1 \%$ \\
\hline 2008 & $14.0 \%$ & $25.3 \%$ & $13.5 \%$ & $20.6 \%$ & $15.6 \%$ & $0.3 \%$ & $10.6 \%$ \\
\hline 2009 & $12.7 \%$ & $24.3 \%$ & $12.7 \%$ & $23.8 \%$ & $15.2 \%$ & $1.4 \%$ & $9.9 \%$ \\
\hline 2010 & $13.4 \%$ & $25.1 \%$ & $13.2 \%$ & $22.2 \%$ & $15.6 \%$ & $0.4 \%$ & $10.2 \%$ \\
\hline Average & $12.8 \%$ & $24.3 \%$ & $15.4 \%$ & $23.1 \%$ & $15.1 \%$ & $0.7 \%$ & $8.7 \%$ \\
\hline
\end{tabular}


Table 7: The relative impact of the causal variables on the shadow economy of GERMANY over 1998 to 2010

\begin{tabular}{|c|c|c|c|c|c|c|c|}
\hline$\frac{\text { Germany }}{\text { Year }}$ & $\begin{array}{c}\text { Personal } \\
\text { Income Tax } \\
\text { (PIT) }\end{array}$ & Indirect taxes & Tax morale & Unemployment & $\begin{array}{c}\text { Self- } \\
\text { employment }\end{array}$ & GDP growth & $\begin{array}{c}\text { Business free- } \\
\text { dom }\end{array}$ \\
\hline 1998 & $17.0 \%$ & $21.4 \%$ & $11.8 \%$ & $25.8 \%$ & $16.4 \%$ & $1.0 \%$ & $6.7 \%$ \\
\hline 1999 & $17.2 \%$ & $22.6 \%$ & $11.4 \%$ & $23.4 \%$ & $16.0 \%$ & $0.9 \%$ & $8.4 \%$ \\
\hline 2000 & $17.8 \%$ & $23.0 \%$ & $11.0 \%$ & $21.8 \%$ & $16.4 \%$ & $1.4 \%$ & $8.6 \%$ \\
\hline 2001 & $18.4 \%$ & $23.7 \%$ & $10.3 \%$ & $21.9 \%$ & $16.7 \%$ & $0.5 \%$ & $8.5 \%$ \\
\hline 2002 & $16.7 \%$ & $24.2 \%$ & $9.6 \%$ & $24.2 \%$ & $16.6 \%$ & $0.1 \%$ & $8.5 \%$ \\
\hline 2003 & $15.7 \%$ & $24.2 \%$ & $8.9 \%$ & $25.8 \%$ & $16.9 \%$ & $0.1 \%$ & $8.4 \%$ \\
\hline 2004 & $14.3 \%$ & $23.6 \%$ & $8.0 \%$ & $27.8 \%$ & $17.4 \%$ & $0.6 \%$ & $8.2 \%$ \\
\hline 2005 & $14.2 \%$ & $23.5 \%$ & $7.2 \%$ & $29.3 \%$ & $17.3 \%$ & $0.4 \%$ & $8.0 \%$ \\
\hline 2006 & $15.0 \%$ & $23.1 \%$ & $6.5 \%$ & $26.9 \%$ & $16.9 \%$ & $1.5 \%$ & $10.1 \%$ \\
\hline 2007 & $16.3 \%$ & $25.4 \%$ & $6.1 \%$ & $23.3 \%$ & $17.2 \%$ & $1.3 \%$ & $10.4 \%$ \\
\hline 2008 & $18.0 \%$ & $26.3 \%$ & $5.7 \%$ & $21.1 \%$ & $17.4 \%$ & $0.6 \%$ & $11.0 \%$ \\
\hline 2009 & $17.1 \%$ & $26.6 \%$ & $5.6 \%$ & $21.1 \%$ & $16.8 \%$ & $2.0 \%$ & $10.7 \%$ \\
\hline 2010 & $17.1 \%$ & $26.0 \%$ & $5.6 \%$ & $21.8 \%$ & $17.1 \%$ & $1.8 \%$ & $10.7 \%$ \\
\hline Average & $16.5 \%$ & $24.1 \%$ & $8.3 \%$ & $24.2 \%$ & $16.9 \%$ & $0.9 \%$ & $9.1 \%$ \\
\hline
\end{tabular}


Table 8: The relative impact of the causal variables on the shadow economy of ITALY over 1998 to 2010

\begin{tabular}{|c|c|c|c|c|c|c|c|}
\hline$\frac{\text { Italy }}{\text { Year }}$ & $\begin{array}{c}\text { Personal } \\
\text { Income Tax } \\
\text { (PIT) }\end{array}$ & Indirect taxes & Tax morale & Unemployment & $\begin{array}{c}\text { Self- } \\
\text { employment }\end{array}$ & GDP growth & $\begin{array}{c}\text { Business free- } \\
\text { dom }\end{array}$ \\
\hline 1998 & $13.6 \%$ & $18.1 \%$ & $8.5 \%$ & $23.6 \%$ & $29.9 \%$ & $0.4 \%$ & $5.9 \%$ \\
\hline 1999 & $14.6 \%$ & $18.4 \%$ & $8.3 \%$ & $22.8 \%$ & $29.5 \%$ & $0.5 \%$ & $5.9 \%$ \\
\hline 2000 & $14.0 \%$ & $18.4 \%$ & $8.5 \%$ & $21.7 \%$ & $30.2 \%$ & $1.2 \%$ & $6.1 \%$ \\
\hline 2001 & $14.9 \%$ & $18.3 \%$ & $8.8 \%$ & $20.0 \%$ & $31.0 \%$ & $0.6 \%$ & $6.3 \%$ \\
\hline 2002 & $14.9 \%$ & $19.0 \%$ & $8.9 \%$ & $19.6 \%$ & $31.1 \%$ & $0.1 \%$ & $6.5 \%$ \\
\hline 2003 & $15.1 \%$ & $18.5 \%$ & $9.0 \%$ & $19.2 \%$ & $31.4 \%$ & $0.3 \%$ & $6.5 \%$ \\
\hline 2004 & $15.1 \%$ & $19.3 \%$ & $9.0 \%$ & $17.2 \%$ & $32.6 \%$ & $0.2 \%$ & $6.6 \%$ \\
\hline 2005 & $15.4 \%$ & $19.8 \%$ & $9.2 \%$ & $17.1 \%$ & $31.6 \%$ & $0.0 \%$ & $6.7 \%$ \\
\hline 2006 & $16.0 \%$ & $19.9 \%$ & $9.2 \%$ & $15.2 \%$ & $31.5 \%$ & $0.5 \%$ & $7.6 \%$ \\
\hline 2007 & $17.0 \%$ & $19.8 \%$ & $9.4 \%$ & $14.0 \%$ & $31.9 \%$ & $0.3 \%$ & $7.6 \%$ \\
\hline 2008 & $17.6 \%$ & $18.5 \%$ & $9.3 \%$ & $15.3 \%$ & $31.0 \%$ & $0.8 \%$ & $7.6 \%$ \\
\hline 2009 & $17.1 \%$ & $17.6 \%$ & $9.0 \%$ & $17.2 \%$ & $29.4 \%$ & $2.1 \%$ & $7.5 \%$ \\
\hline 2010 & $17.4 \%$ & $18.7 \%$ & $9.3 \%$ & $15.6 \%$ & $31.0 \%$ & $0.3 \%$ & $7.7 \%$ \\
\hline Average & $15.6 \%$ & $18.8 \%$ & $9.0 \%$ & $18.4 \%$ & $30.9 \%$ & $0.6 \%$ & $6.8 \%$ \\
\hline
\end{tabular}


Table 9: The relative impact of the causal variables on the shadow economy of SPAIN over 1998 to 2010

\begin{tabular}{|c|c|c|c|c|c|c|c|}
\hline$\frac{\text { Spain }}{\text { Year }}$ & $\begin{array}{c}\text { Personal } \\
\text { Income Tax } \\
\text { (PIT) }\end{array}$ & Indirect taxes & Tax morale & Unemployment & $\begin{array}{c}\text { Self- } \\
\text { employment }\end{array}$ & GDP growth & $\begin{array}{c}\text { Business free- } \\
\text { dom }\end{array}$ \\
\hline 1998 & $8.7 \%$ & $18.2 \%$ & $8.0 \%$ & $35.2 \%$ & $22.9 \%$ & $1.3 \%$ & $5.7 \%$ \\
\hline 1999 & $9.0 \%$ & $20.4 \%$ & $8.1 \%$ & $31.7 \%$ & $23.2 \%$ & $1.4 \%$ & $6.2 \%$ \\
\hline 2000 & $9.1 \%$ & $21.5 \%$ & $8.7 \%$ & $29.8 \%$ & $23.0 \%$ & $1.5 \%$ & $6.5 \%$ \\
\hline 2001 & $10.2 \%$ & $22.7 \%$ & $9.7 \%$ & $24.5 \%$ & $24.8 \%$ & $1.0 \%$ & $7.1 \%$ \\
\hline 2002 & $10.7 \%$ & $18.0 \%$ & $10.4 \%$ & $28.0 \%$ & $24.9 \%$ & $0.5 \%$ & $7.5 \%$ \\
\hline 2003 & $10.6 \%$ & $18.2 \%$ & $10.8 \%$ & $28.2 \%$ & $24.2 \%$ & $0.6 \%$ & $7.6 \%$ \\
\hline 2004 & $10.4 \%$ & $18.0 \%$ & $11.1 \%$ & $27.8 \%$ & $24.4 \%$ & $0.7 \%$ & $7.7 \%$ \\
\hline 2005 & $11.2 \%$ & $18.7 \%$ & $11.7 \%$ & $24.1 \%$ & $25.4 \%$ & $0.8 \%$ & $8.0 \%$ \\
\hline 2006 & $12.0 \%$ & $18.4 \%$ & $12.0 \%$ & $22.5 \%$ & $25.1 \%$ & $1.0 \%$ & $9.0 \%$ \\
\hline 2007 & $13.2 \%$ & $17.0 \%$ & $12.5 \%$ & $22.3 \%$ & $25.2 \%$ & $0.8 \%$ & $9.1 \%$ \\
\hline 2008 & $12.1 \%$ & $14.7 \%$ & $12.0 \%$ & $28.7 \%$ & $23.8 \%$ & $0.3 \%$ & $8.6 \%$ \\
\hline 2009 & $9.8 \%$ & $11.5 \%$ & $10.4 \%$ & $39.6 \%$ & $19.8 \%$ & $1.6 \%$ & $7.3 \%$ \\
\hline 2010 & $11.7 \%$ & $14.3 \%$ & $11.7 \%$ & $31.0 \%$ & $22.9 \%$ & $0.2 \%$ & $8.1 \%$ \\
\hline Average & $10.7 \%$ & $17.8 \%$ & $10.6 \%$ & $28.7 \%$ & $23.8 \%$ & $0.9 \%$ & $7.6 \%$ \\
\hline
\end{tabular}


Table 10: Average relative impact (in \%) of the causal variables on the shadow economy of 38 OECD countries over 1999 to 2010

\begin{tabular}{|c|c|c|c|c|c|c|c|c|}
\hline Country & $\begin{array}{l}\text { Average } \\
\text { size of the } \\
\text { shadow } \\
\text { economy }\end{array}$ & $\begin{array}{c}\text { Personal } \\
\text { income } \\
\text { tax }\end{array}$ & $\begin{array}{c}\text { Indirect } \\
\text { taxes }\end{array}$ & $\begin{array}{c}\text { Tax } \\
\text { morale }\end{array}$ & $\begin{array}{c}\text { Unem- } \\
\text { ployment }\end{array}$ & $\begin{array}{c}\text { Self- } \\
\text { employ- } \\
\text { ment }\end{array}$ & $\begin{array}{l}\text { GDP } \\
\text { growth }\end{array}$ & $\begin{array}{l}\text { Business } \\
\text { freedom }\end{array}$ \\
\hline Australia & 13.8 & 21.3 & 25.4 & 7.4 & 15.8 & 19.3 & 0.9 & 9.9 \\
\hline Austria & 9.8 & 18.5 & 27.4 & 11.6 & 12.1 & 20.5 & 0.8 & 9.1 \\
\hline Belgium & 21.5 & 19.2 & 20.2 & 19.1 & 16.5 & 17.3 & 0.4 & 7.2 \\
\hline Bulgaria & 34.6 & 5.1 & 37.7 & 5.7 & 25.9 & 17.5 & 1.9 & 6.2 \\
\hline Canada & 15.6 & 22.1 & 17.5 & 7.7 & 19.2 & 22.4 & 0.7 & 10.4 \\
\hline Chile & 19.4 & 1.8 & 35.3 & 5.5 & 17.3 & 32.7 & 0.8 & 6.7 \\
\hline Cyprus & 27.2 & 4.3 & 35.9 & 9.1 & 11.2 & 29.9 & 0.8 & 8.7 \\
\hline Czech Rep. & 17.6 & 7.8 & 30.7 & 9.4 & 19.0 & 23.5 & 1.2 & 8.3 \\
\hline Denmark & 17.3 & 34.6 & 33.5 & 4.0 & 9.5 & 9.9 & 0.3 & 8.2 \\
\hline Estonia & 21.7 & 10.0 & 36.0 & 11.7 & 21.8 & 10.4 & 1.8 & 8.3 \\
\hline Finland & 17.4 & 19.7 & 29.1 & 8.7 & 18.6 & 15.2 & 0.8 & 7.9 \\
\hline France & 14.8 & 12.8 & 24.3 & 15.5 & 23.2 & 15.1 & 0.4 & 8.6 \\
\hline Germany & 15.7 & 16.6 & 24.2 & 8.3 & 24.3 & 16.9 & 0.6 & 9.1 \\
\hline Greece & 27.0 & 5.8 & 21.8 & 10.4 & 18.0 & 37.6 & 0.7 & 5.7 \\
\hline Hungary & 24.1 & 12.3 & 34.9 & 6.4 & 18.6 & 18.5 & 1.2 & 8.0 \\
\hline Iceland & 15.2 & 19.9 & 39.7 & 6.5 & 7.1 & 17.9 & 0.6 & 8.2 \\
\hline Ireland & 16.1 & 12.5 & 36.4 & 7.9 & 12.5 & 21.3 & 1.0 & 8.5 \\
\hline Italy & 26.9 & 15.6 & 18.9 & 9.0 & 18.6 & 31.0 & 0.1 & 6.8 \\
\hline Korea & 26.3 & 5.7 & 27.3 & 3.4 & 9.8 & 44.3 & 1.4 & 8.0 \\
\hline Latvia & 22.2 & 8.2 & 32.3 & 13.3 & 23.3 & 14.6 & 1.8 & 6.6 \\
\hline Lithuania & 25.4 & 9.0 & 28.8 & 17.5 & 19.9 & 17.1 & 1.5 & 6.1 \\
\hline Luxembourg & 9.6 & 13.2 & 33.4 & 20.0 & 10.4 & 11.9 & 1.2 & 9.8 \\
\hline Malta & 27.3 & 5.9 & 39.7 & 3.2 & 20.0 & 21.2 & 0.8 & 9.3 \\
\hline Mexico & 30.0 & 2.3 & 42.1 & 10.2 & 5.9 & 33.8 & 0.4 & 5.3 \\
\hline Netherlands & 13.2 & 13.6 & 32.5 & 13.0 & 10.4 & 19.7 & 0.8 & 10.0 \\
\hline New Zealand & 12.2 & 21.8 & 25.4 & 8.4 & 11.9 & 22.9 & 0.6 & 9.1 \\
\hline Norway & 18.6 & 21.2 & 31.5 & 12.5 & 10.8 & 13.0 & 0.5 & 10.5 \\
\hline Poland & 26.4 & 6.1 & 27.8 & 7.8 & 26.1 & 25.7 & 1.3 & 5.3 \\
\hline Portugal & 22.7 & 8.1 & 29.9 & 8.7 & 14.6 & 31.1 & 0.4 & 7.2 \\
\hline Romania & 32.2 & 4.2 & 24.5 & 14.2 & 13.1 & 37.7 & 1.1 & 5.2 \\
\hline Slovak Rep. & 17.5 & 4.8 & 31.7 & 6.4 & 34.9 & 13.7 & 1.5 & 7.1 \\
\hline Slovenia & 25.2 & 9.6 & 33.9 & 9.6 & 15.4 & 21.7 & 1.2 & 8.6 \\
\hline Spain & 22.8 & 10.6 & 17.9 & 10.4 & 29.2 & 23.8 & 0.6 & 7.5 \\
\hline Sweden & 18.6 & 23.5 & 30.6 & 8.7 & 15.2 & 13.2 & 0.8 & 8.0 \\
\hline Switzerland & 8.3 & 17.7 & 30.7 & 9.0 & 9.6 & 23.8 & 0.5 & 8.7 \\
\hline Turkey & 30.6 & 4.9 & 31.4 & 0.7 & 16.4 & 41.4 & 0.6 & 4.6 \\
\hline United Kingdom & 12.5 & 18.2 & 30.8 & 8.1 & 14.3 & 18.0 & 0.6 & 9.9 \\
\hline United States & 8.7 & 27.5 & 5.1 & 13.2 & 22.0 & 16.0 & 0.9 & 15.4 \\
\hline Average & 20.3 & 13.1 & 29.4 & 9.5 & 16.9 & 22.2 & 0.9 & 8.1 \\
\hline
\end{tabular}




\section{FIGURES}

Figure 1: Relative impact of the causes on the Austrian shadow economy (1998 to 2010)

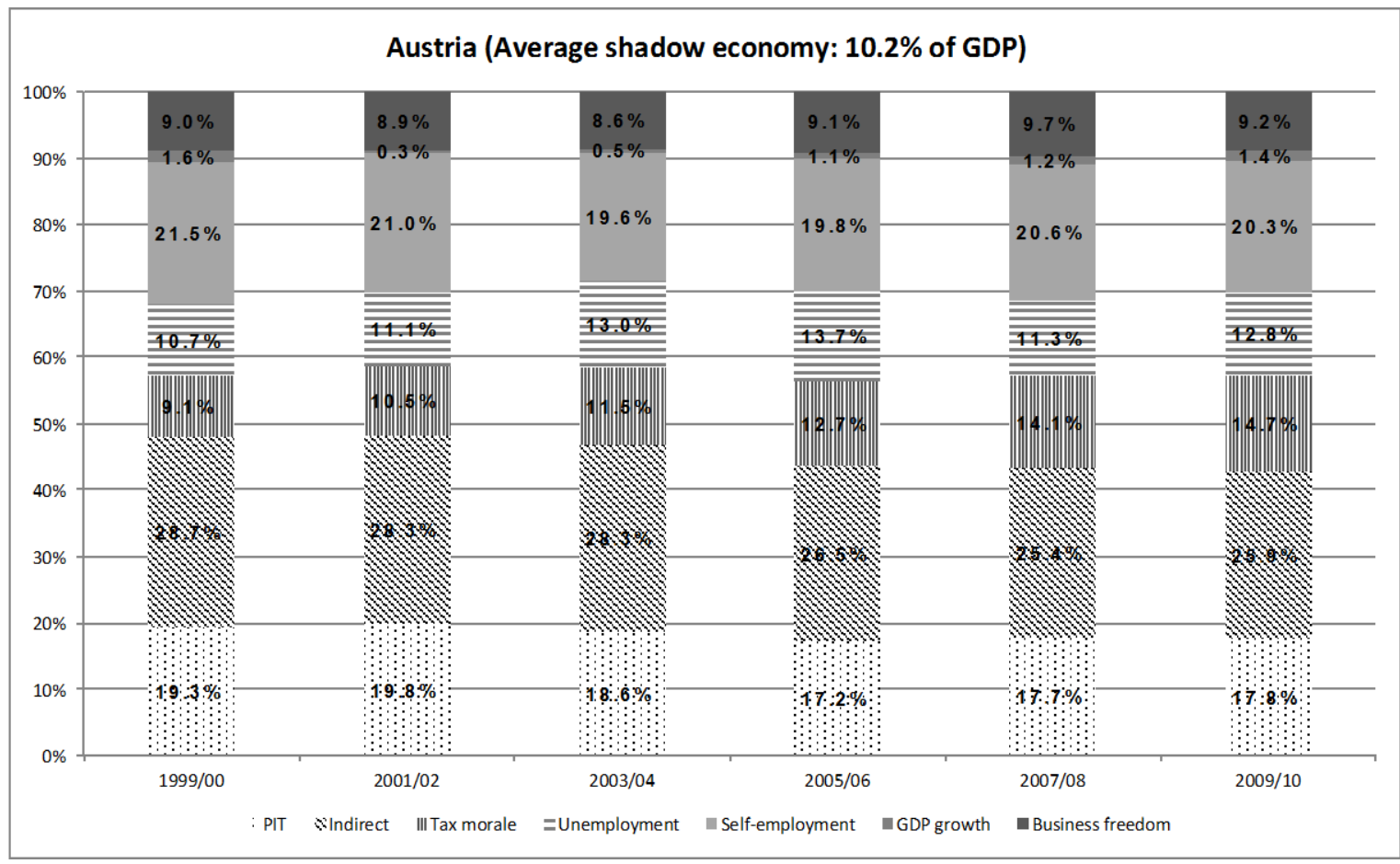

Figure 2: Relative impact of the causes on the French shadow economy (1998 to 2010)

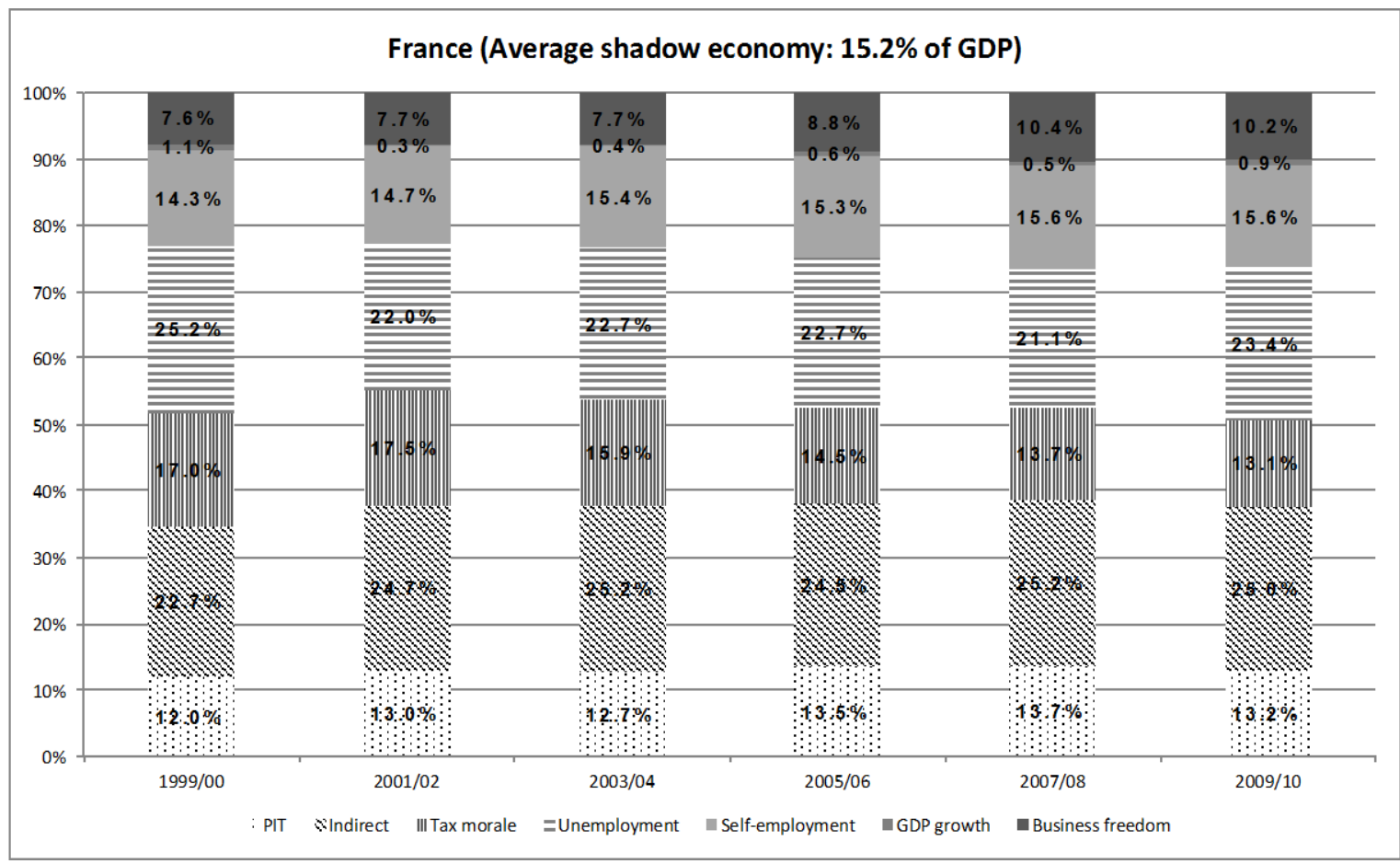


Figure 3: Relative impact of the causes on the German shadow economy (1998 to 2010)

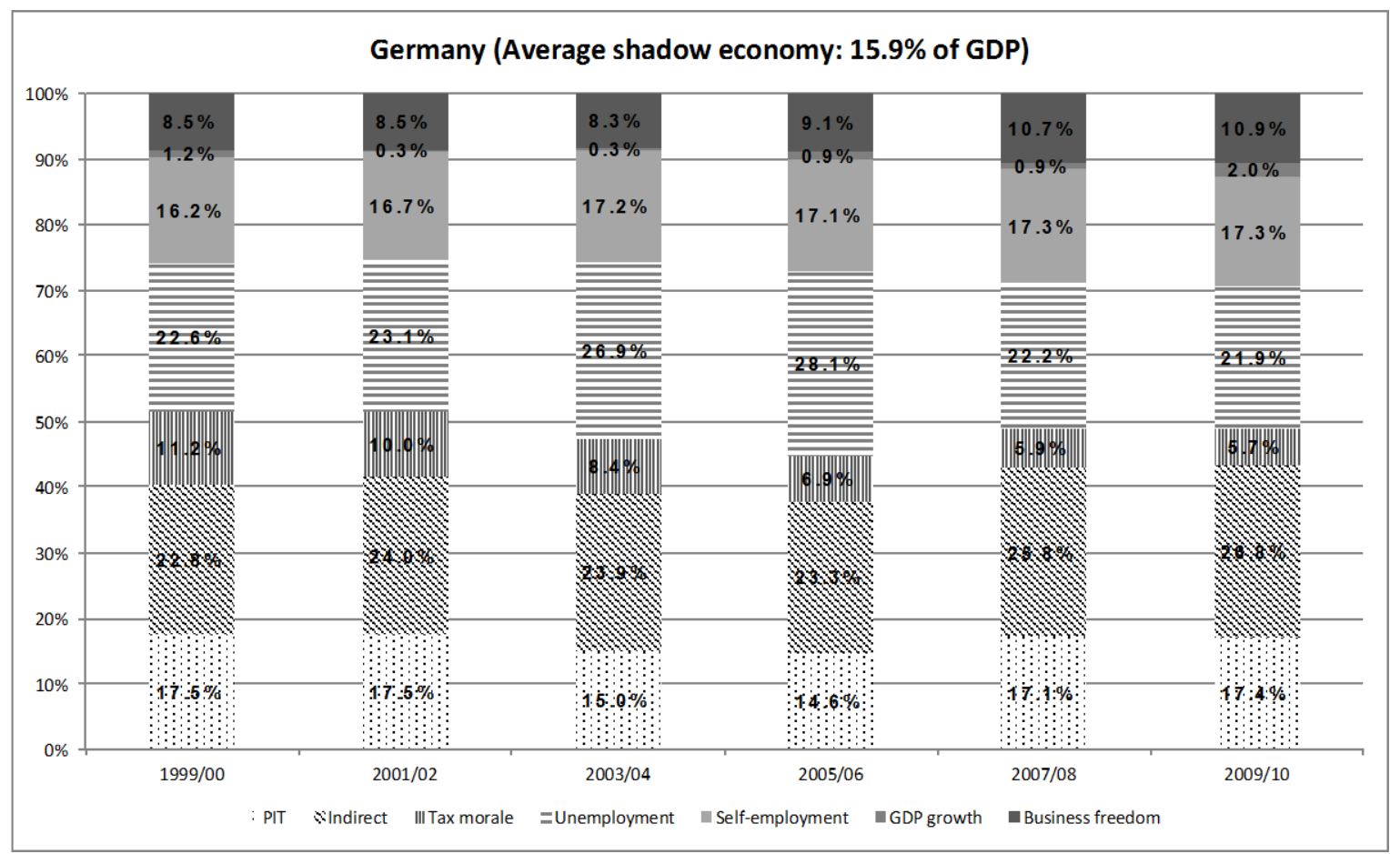

Figure 4: Relative impact of the causes on the Italian shadow economy (1998 to 2010)

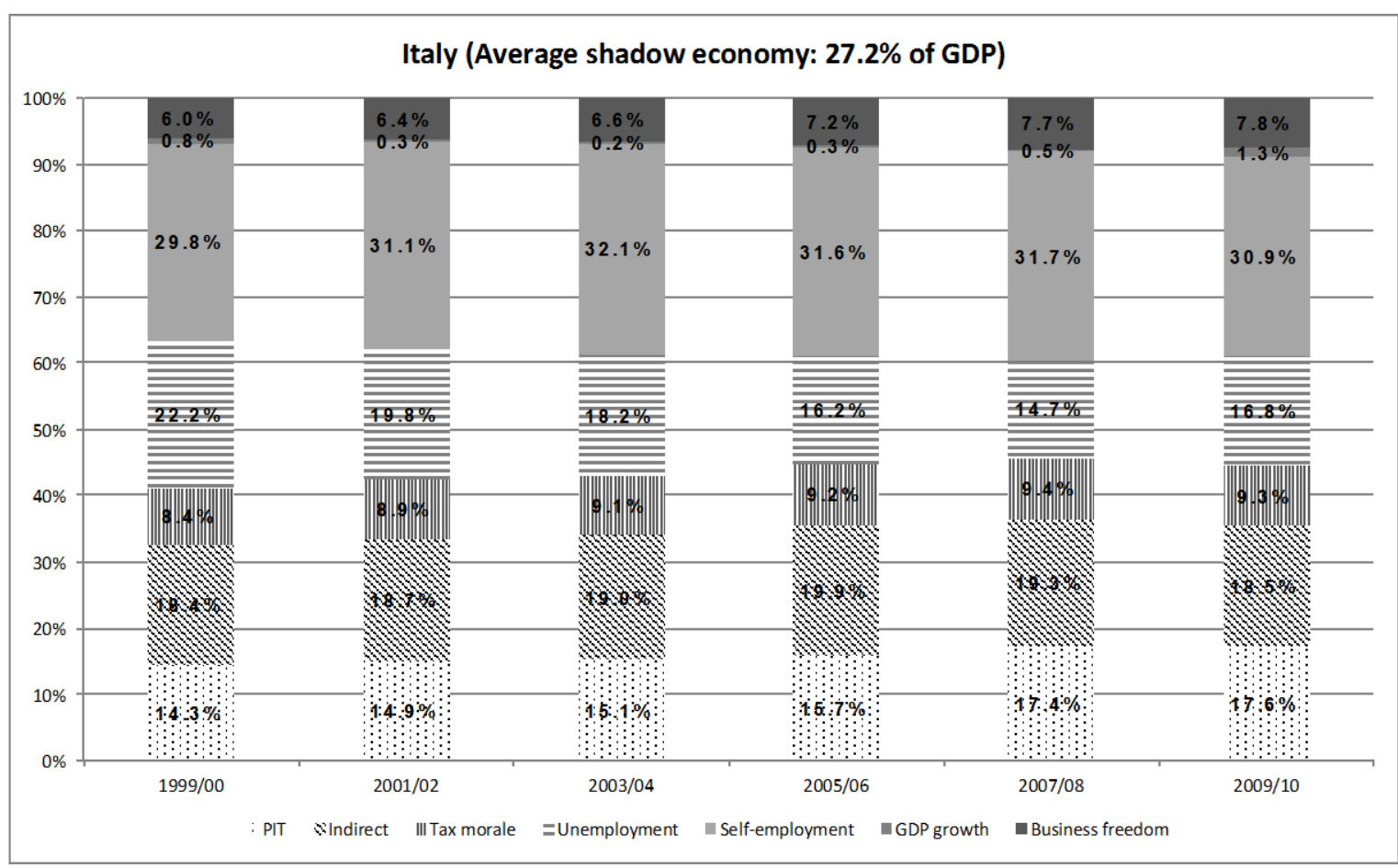


Figure 5: Relative impact of the causes on the Spanish shadow economy (1998 to 2010)

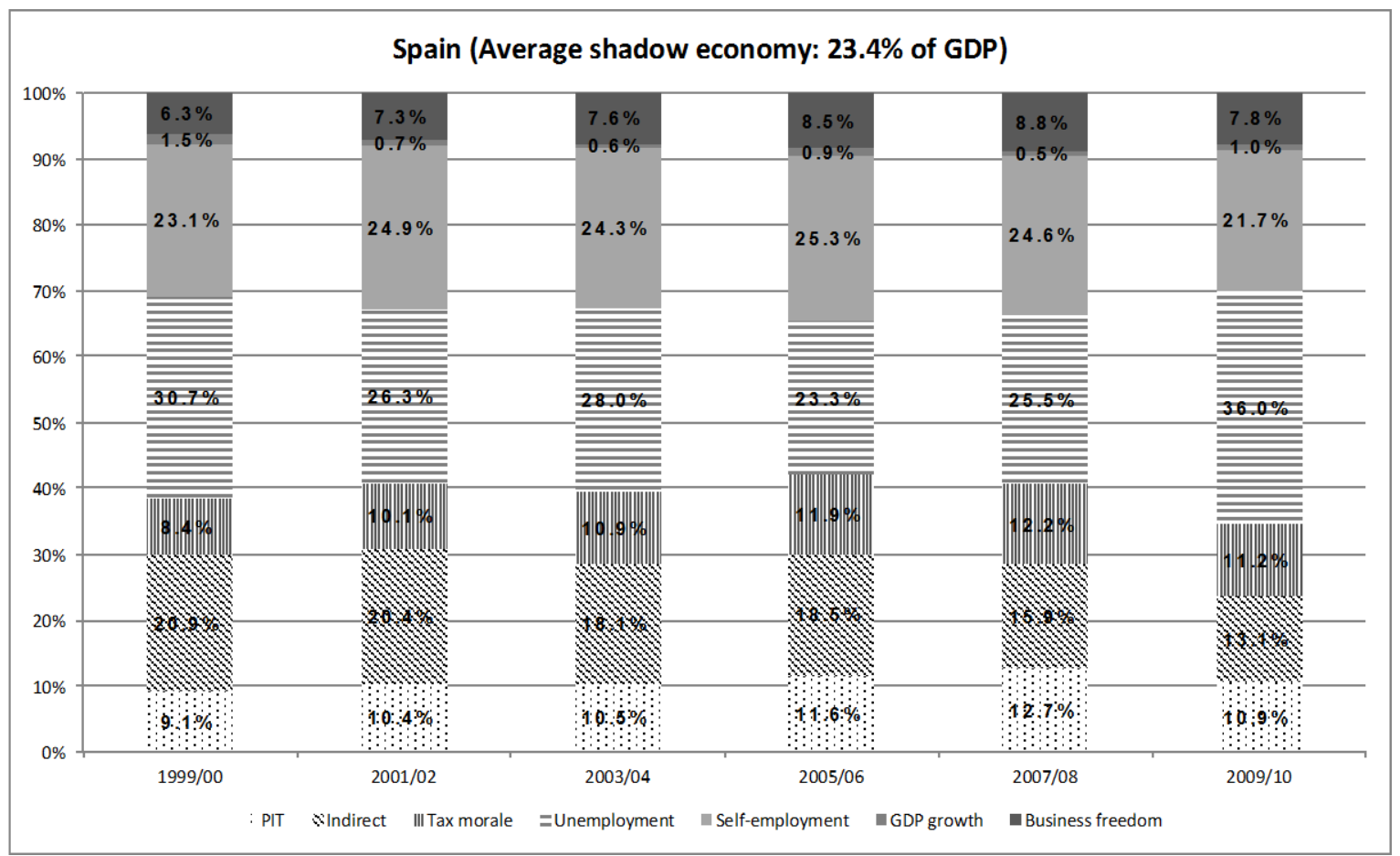




\section{REFERENCES}

Allingham, M.G. and A. Sandmo (1972), Income Tax Evasion: A Theoretical Analysis, Journal of Public Economics 1/3, pp. 323-338.

Andreoni, J., B. Erard and J. Feinstein (1998), Tax Compliance, Journal of Economic Literature 36/4, pp. 818-860.

Bhattacharyya, D.K. (1999), On the Economic Rationale of Estimating the Hidden Economy, Economic Journal 109/3, 348-359.

Breusch, T. (2005a), The Canadian Underground Economy: An Examination of Giles and Tedds, Canadian Tax Journal 53/4, 367-391.

Buehn, A. (2012), The Shadow Economy in German Regions: An Empirical Assessment, German Economic Review 13(3), 275-290.

Buehn, A. and S. Eichler (2009), Smuggling Illegal versus Legal Goods across the U.S.Mexico Border: A Structural Equations Model Approach,” Southern Economic Journal 76, 328-350.

Buehn, A. and F. Schneider (2012), Shadow Economies Around the World: Novel Insights, Accepted Knowledge, and New Estimates, International Tax and Public Finance 19, 139-171.

Buehn, A., A. Karmann and F. Schneider (2009), Shadow Economy and Do-it-yourself Activities: The German Case, Journal of Institutional and Theoretical Economics 165 (4), 701-722.

Dell'Anno R. (2007), The Shadow Economy in Portugal: An Analysis with the MIMIC Approach, Journal of Applied Economics 10, 253-277.

Dell'Anno R., M. Gomez-Antonio and A. Alanon Pardo (2007), Shadow Economy in three different Mediterranean Countries: France, Spain and Greece. A MIMIC Approach, Empirical Economics 33, 51-84.

Dreher, A. and F. Schneider (2009) Corruption and the Shadow Economy: An Empirical Analysis, Public Choice, 144/2, pp.215-277.

Dreher, A., C. Kotsogiannis and S. McCorriston (2009), How Do Institutions Affect Corruption and the Shadow Economy?, International Tax and Public Finance, 16/4, pp.773796.

Enste, D. and F. Schneider (2006), Umfang und Entwicklung der Schattenwirtschaft in 145 Ländern, in: F. Schneider and D. Enste (eds.), Jahrbuch Schattenwirtschaft 2006/07. Zum Spannungsfeld von Poltik und Ökonomie, LIT Verlag, Berlin, 55-80.

Feige, E.L. (ed.) (1989), The Underground Economies. Tax Evasion and Information Distortion, Cambridge University Press, Cambridge.

Feld, L.P. and B.S. Frey (2007), Tax Compliance as the Result of a Psychological Tax Contract: The Role of Incentives and Responsive Regulation, Law and Policy 29/1, pp. 102-120. 
Feld, L.P. and C. Larsen (2005), Black Activities in Germany in 2001 and 2004: A Comparison Based on Survey Data, Study No. 12, The Rockwool Foundation Research Unit, Copenhagen.

Feld, L.P. and C. Larsen (2009), Undeclared Work in Germany 2001-2007 - Impact of Deterrence, Tax Policy, and Social Norms: An Analysis Based on Survey Data, Springer, Berlin et al.

Feld, L.P. and F. Schneider (2010), Survey on the Shadow Economy and Undeclared Earnings in OECD Countries, German Economic Review 11/2, pp. 109-149.

Friedman, E., S. Johnson, D. Kaufmann and P. Zoido-Lobatón (2000), Dodging the Grabbing Hand: The Determinants of Unofficial Activity in 69 Countries, Journal of Public Economics 76/4, pp. 459-493.

Giles, D.E.A. (1999), Measuring the Hidden Economy: Implications for Econometric Modelling, Economic Journal 109/3, 370-380.

Isachsen, A.J. and S. Strøm (1985), The Size and Growth of the Hidden Economy in Norway, Review of Income and Wealth 31/1, 21-38.

Johnson, S., D. Kaufmann and P. Zoido-Lobatón (1998a), Regulatory Discretion and the Unofficial Economy, American Economic Review, Papers and Proceedings 88 (2), 387-392.

Johnson, S., D. Kaufmann and P. Zoido-Lobatón (1998b), Corruption, Public Finances and the Unofficial Economy, World Bank Policy Research Working Paper Series No. 2169, The World Bank, Washington, D.C.

Johnson, S., D. Kaufmann and A. Shleifer (1997), The Unofficial Economy in Transition, Brookings Papers on Economic Activity No. 2, pp. 159-221.

Kanniainen, V., J. Pääkönen and F. Schneider (2004), Fiscal and Ethical Determinants of Shadow Economy: Theorey and Evidence, Discussion Paper, Department of Economics, Johannes Kepler University of Linz, Linz, Austria.

Kirchler, E. (2007), The Economic Psychology of Tax Behaviour, Cambridge (UK) University Press, Cambridge.

Kucera, D. and L. Roncolato (2008), Informal Employment: Two Contested Policy Issues, International Labor Review 147/3, 321-348.

Marcelli, E.A. (2004), Unauthorized Mexican Immigration, the Labour and other LowerWage Informal Employment in California, Regional Studies 38/1, pp. 1-13.

Pedersen, S. (2003), The Shadow Economy in Germany, Great Britain and Scandinavia: A Measurement Based on Questionnaire Service, Study No. 10, The Rockwool Foundation Research Unit, Copenhagen.

Posner, E.A. (2000a), Law and Social Norms, Harvard University Press. Cambridge. 
Renooy, P., S. Ivarsson, O. van der Wusten-Gritsai and E. Meijer (2004), Undeclared Work in an Enlarged Union - An Analysis of Undeclared Work: An In-Depth Study of Specific Items, European Commission, Brussels.

Schneider, F. (2003), Shadow Economy, in: C.K. Rowley and F. Schneider (eds.), Encyclopedia of Public Choice Vol. II, Kluwer Academic Publishers, Dordrecht, 286-296.

Schneider, F. (2005), Shadow Economies around the World: What Do We Really Know? European Journal of Political Economy 21/4, 598-642.

Schneider, F. (2010), The Influence of Public Institutions on the Shadow Economy: An Empirical Investigation for OECD Countries, European Journal of Law and Economics, 6/3, pp.441-468.

Schneider, F. (eds.), (2011), Handbook on the Shadow Economy, Cheltenham (UK), Edward Elgar Publishing Company.

Schneider, F. and D. Enste (2000), Shadow Economies: Size, Causes and Consequences, Journal of Economic Literature 38/1, 73-110.

Tafenau, E., H. Herwartz and F. Schneider (2010), Regional Estimates for the Shadow Economy in Europe, International Economic Journal, 24/4, pp. 629-636.

Tanzi, V. (1999), Uses and Abuses of Estimates of the Underground Economy, Economic Journal 109/3, 338-347.

Teobaldelli, D. (2011), Federalism and the Shadow Economy, Public Choice (2011) 146/3, pp. 269-269.

Teobaldelli, D. and F. Schneider (2012), Beyond the veil of ignorance: The influence of direct democracy on the shadow economy, CESifo Working Paper MO3749, University of Munich, Munich.

Thomas, J.J. (1992), Informal Economic Activity, Harvester/Weatsheaf, New York et al.

Thomas, J.J. (1999), Quantifying the Black Economy: 'Measurement Without Theory' Yet Again?, Economic Journal 109, 381-389.

Torgler, B. and F. Schneider (2009), The Impact of Tax Morale and Institutional Quality on the Shadow Economy, Journal of Economic Psychology 30/3, 228-245.

Williams, C.C. and J. Windebank (2001), Reconceptualizing Paid Informal Exchange: Some Lessons from English Cities, Environment and Planning A 33, 121-140. 


\section{APPENDIX}

Table A.1: Definitions, expected signs and sources of the causal and indicator variables

\begin{tabular}{|c|c|c|}
\hline Causal Variable & Description and source & $\begin{array}{l}\text { Expected } \\
\text { sign }\end{array}$ \\
\hline Business freedom & $\begin{array}{l}\text { Business freedom index measuring the time and efforts of busi- } \\
\text { ness activity ranging; } 0=\text { least business freedom, and } 100= \\
\text { maximum business freedom; Heritage Foundation }\end{array}$ & - \\
\hline Corruption & $\begin{array}{l}\text { Corruption index (score between } 0 \text { and } 100 \text { with higher values } \\
\text { indicating more corruption); Heritage Foundation }\end{array}$ & + \\
\hline Education & $\begin{array}{l}\text { Secondary school enrolment rate (\% gross); World Develop- } \\
\text { ment Indicators (WDI) }\end{array}$ & - \\
\hline GDP growth & GDP per capita growth, annual (\%); WDI & $+/-$ \\
\hline Indirect taxes & Taxes on goods and services (\% of total tax revenue); WDI & + \\
\hline Payroll taxes & $\begin{array}{l}\text { Taxes on income, profits and capital gains (\% of total tax reve- } \\
\text { nue); WDI }\end{array}$ & + \\
\hline Personal income tax & $\begin{array}{l}\text { Personal Income Tax (PIT) to GDP, Government Finance Sta- } \\
\text { tistics; International Monetary Fund }\end{array}$ & + \\
\hline Rule of Law & $\begin{array}{l}\text { Rule of Law index summarizing the quality of contract en- } \\
\text { forcement, the police, and the courts, as well as the likelihood of } \\
\text { crime and violence, }-2.5 \text { = no compliance, and } 2.5 \text { = total com- } \\
\text { pliance; World Bank Governance Indicators }\end{array}$ & - \\
\hline Self-employment & $\begin{array}{l}\text { Total self-employed workers (proportion of total employment); } \\
\text { WDI }\end{array}$ & + \\
\hline Tax morale & $\begin{array}{l}\text { To assess the level of tax morale we use the following question: } \\
\text { "'Please tell me for each of the following statements whether } \\
\text { you think it can always be justified, never be justified, or some- } \\
\text { thing in between: .. Cheating on tax if you have the chance". } \\
\text { The question leads to a 10-scale index of tax morale with the } \\
\text { two extreme points "'never justified"' (1) and "always justi- } \\
\text { fied" (10). Using the proportion of respondents who answered } \\
\text { the question with a value of } 6 \text { or higher, higher values of our tax } \\
\text { morale variable indicate a lower level of tax moral; European } \\
\text { and World Value Surveys }\end{array}$ & - \\
\hline Unemployment & Unemployment rate (\% of total labor force; WDI & + \\
\hline $\begin{array}{l}\text { Currency in circula- } \\
\text { tion }\end{array}$ & $\begin{array}{l}\text { Monetary aggregates M0 over M1; International Monetary } \\
\text { Fund, International Financial Statistics }\end{array}$ & + \\
\hline GDP pc & GDP per capita, PPP (constant 2005 international \$); WDI & - \\
\hline $\begin{array}{l}\text { Labour force partici- } \\
\text { pation }\end{array}$ & Labor force participation rate (\% of total population); WDI & - \\
\hline
\end{tabular}

